
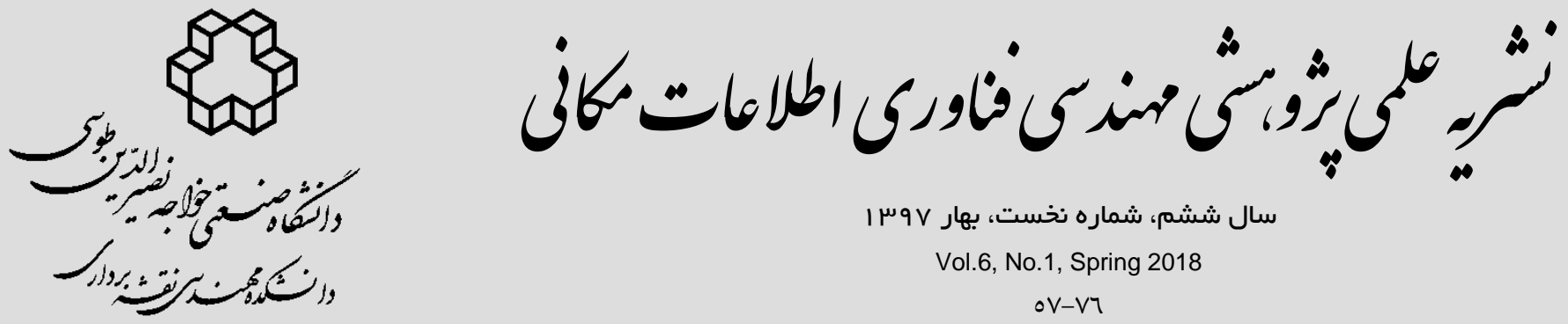

Ir س سال ششم، شماره نخست، بهار

Vol.6, No.1, Spring 2018

oV-VI

ارزيابى آسيبذيذيرى لرزهاى شبكه حمل و نقل با تأكيد بر معيارهاى مقاومت زمين و طراحى

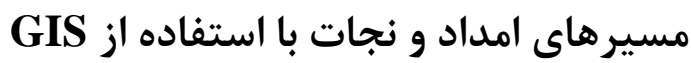

\author{
عبدالرضا كاظمى نيا"'، عليرضا غنى زاده׳

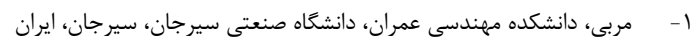

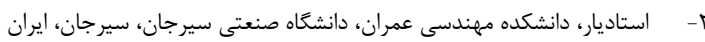

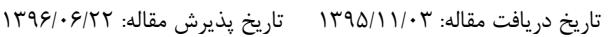

جكيده

اهميت شبكه حمل و نقل در بخش اقتصاد، صنعت، سياست و حتى نظامى سبب شده كه زيربناى توسعه يايدار در هر منطقه باشد. شـبكه

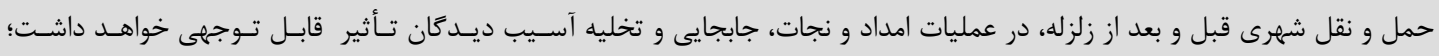

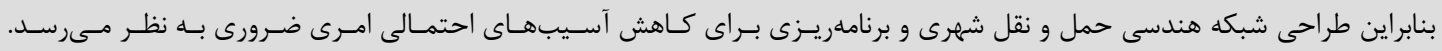

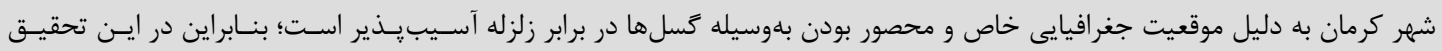

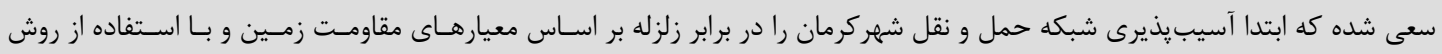

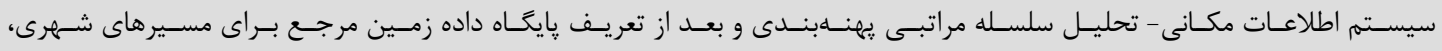

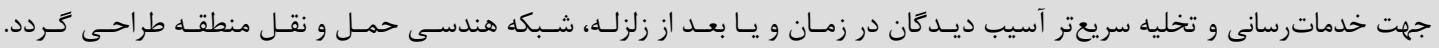

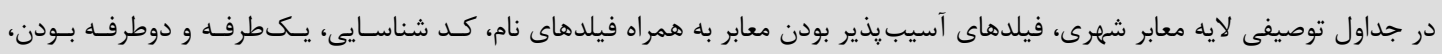

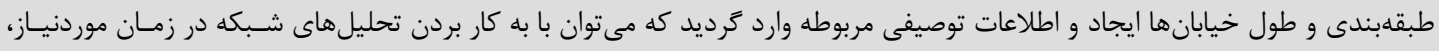

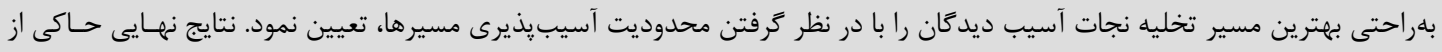

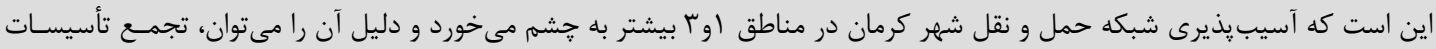

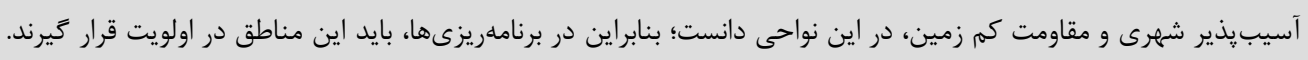

كليدوازهها: شبكه حمل و نقل شهرى، آسيب پِذيرى، شبكه هندسى، پايعاه داده زمين مرجع، زلزله.

نويسنده مكاتبه كننده: سيرجان، كيلومتر ه جاده بافت، دانشكاه صنعتى سيرجان

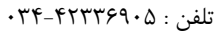




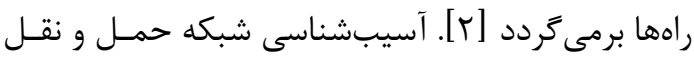

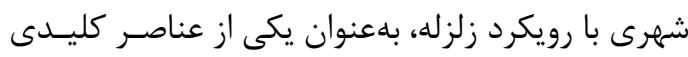

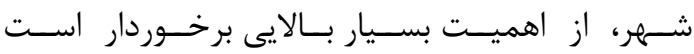

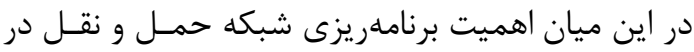

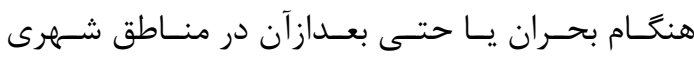

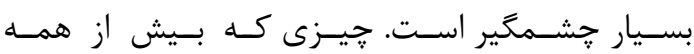

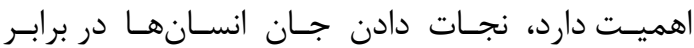

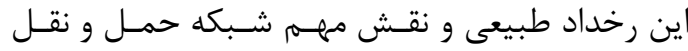

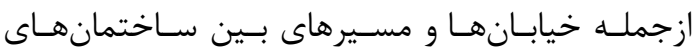
تخريبشده در امدادرسانى و كمك به مجروحين اسـت انست

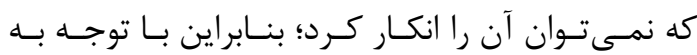

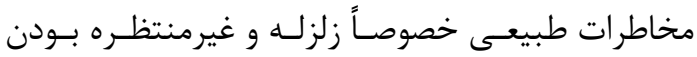

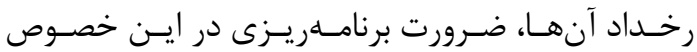

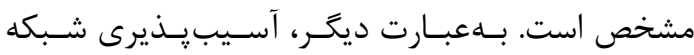

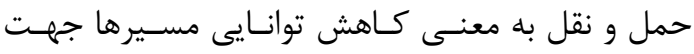
خدماترسانى در هنكام بحران است [ץ]. شبكه حمل و نقل يكى از عناصر مهم شهرى است كه بلافاصله بعد از

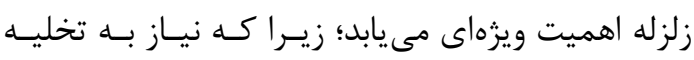

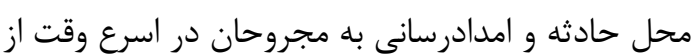
نخستين كامهاى مديريت بحران است كه اين امر جز باد إنا

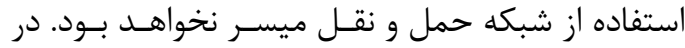
ميان شبكههاى كوناكون شريانهاى حياتى، شبكههـاى حمل و نقل درونشهريبه عنوان آسيبذيذيرترين شبكه

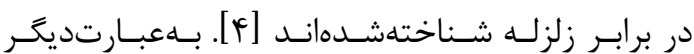

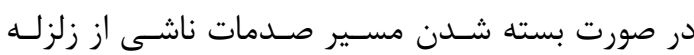
جندين برابر شده و ممكن است بازگشت به وضع عادى

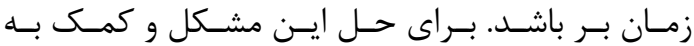

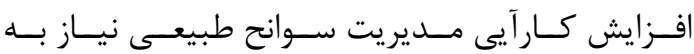

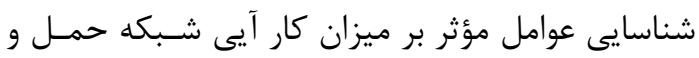

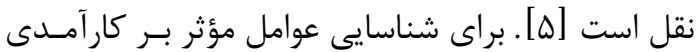

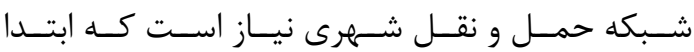

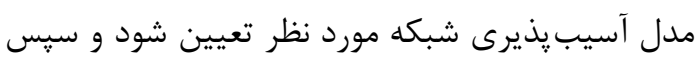
شبكه هندسى براى مشـخص كـردن بهتـرين مسـير و دسترسى به فضاهاى امن جهـت فـرار و نجـات آسـيب مندي ديدكان از زلزله طراحى شود.
- 1 - 1 - 1قدمه

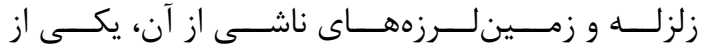

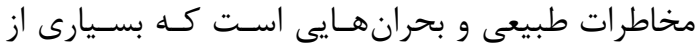

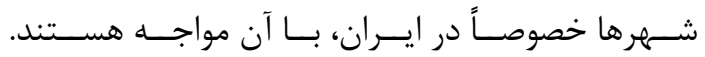

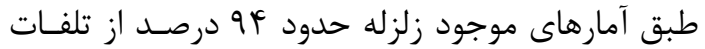

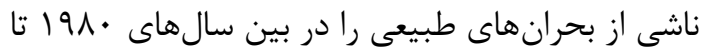

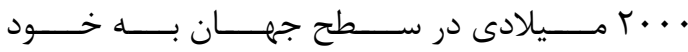
اختصاص داده است و كشور ايــان در ايـن ميــان جـزو

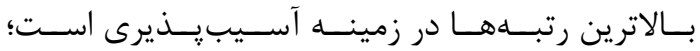
بنابراين شناخت روشهاى كاهش تلفـات، از ضــروريات

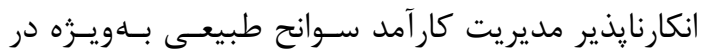
شهرهاى بزرى است. همجنــين زلزلـه يكى از بلايـاى

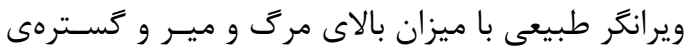

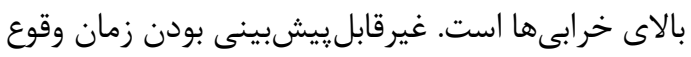

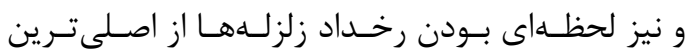
خصوصيات زلزلهها هستند كه آنهـا را از سـاير بلايـاى زئل

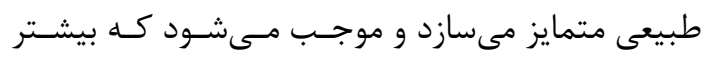

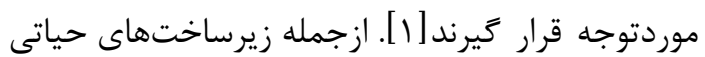
يك شهر كه در اثر وقوع زلزله دجار تخريب مسىشـوند،

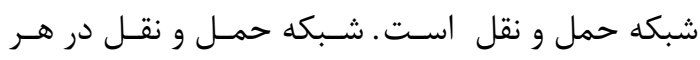

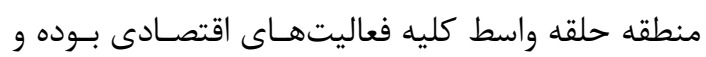

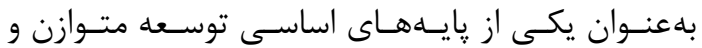
پايدار است. لزوم گسترش شبكه حمل و نقل در شهرها

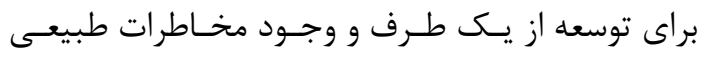
(زلزله، سيل و غيره) از سوى ديخر دو تضاد بـيش آهـده

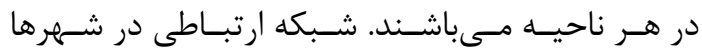

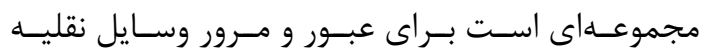
موتورى، دوجرخه و وياده. با اين تعريـف طبيعى اسـت كه شبكه ارتباطى نقش اساسى در كاهش آسيبيذيرى

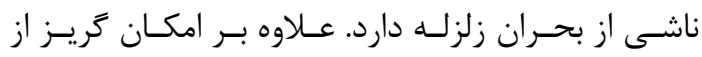

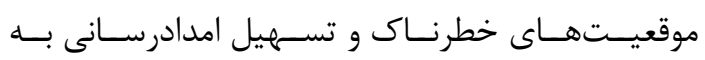

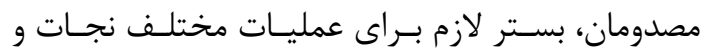
بازسازى را فراهم مىنمايند. در اغلب منـاطق زلز لـهزيده

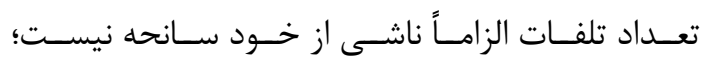
بلكه مشكل عمده به راهبنـدان و مسـدود شـدن شـبكه 


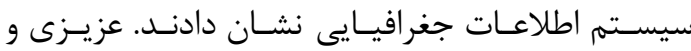

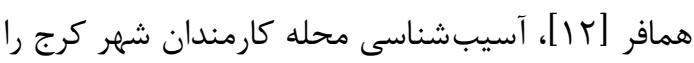

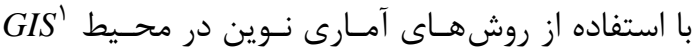

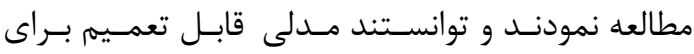

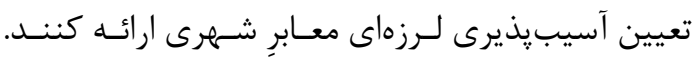

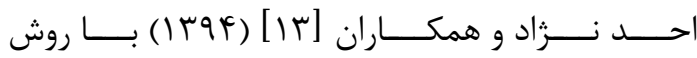

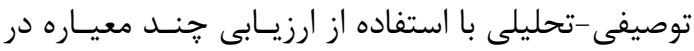

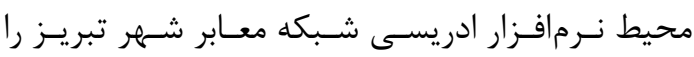

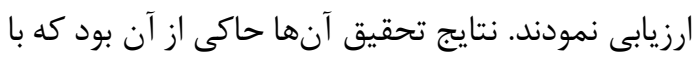

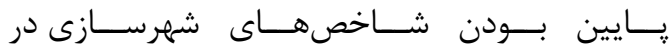

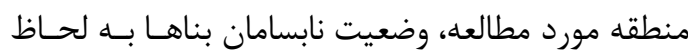

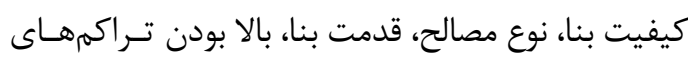

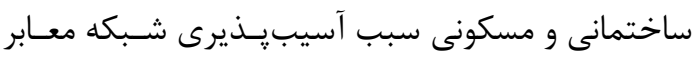

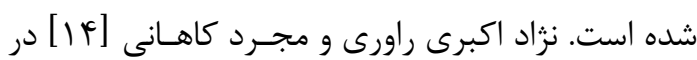

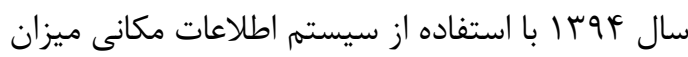

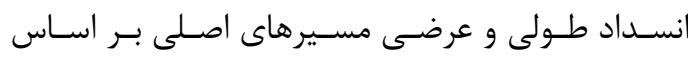
موقعيت مراكز انتظامى شهر كرمان و ميزان كارايى آنها مانها

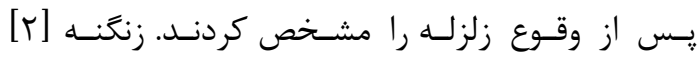

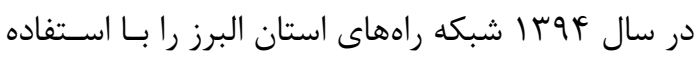

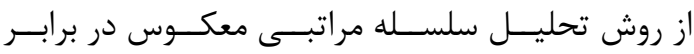

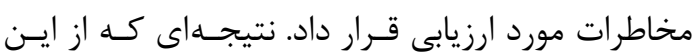

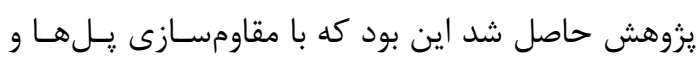

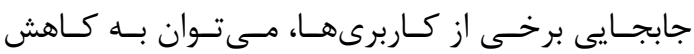

آسيب پايذيرى شبكه راههاى استان البرز اقدام نمود.

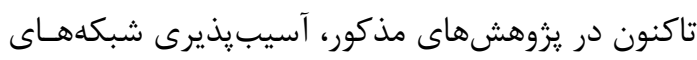

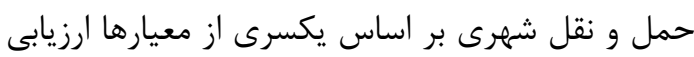

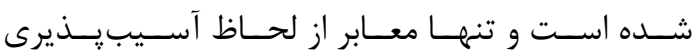

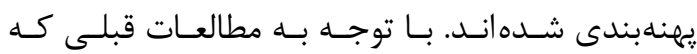

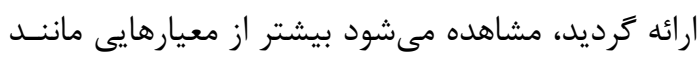

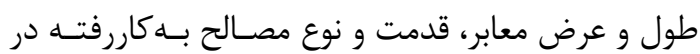

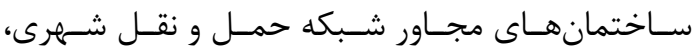

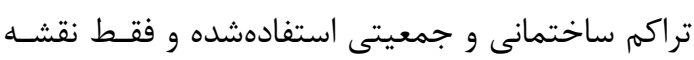
آسيب يذيرى معابر شهرى را تهيه نمودهاند، درحالى كـهـ

\footnotetext{
${ }^{1}$ Geospatial Information System
}

تاكنون تحقيقات مختلفـى در خصـوص آسـيب پـذيرى

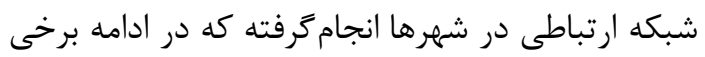

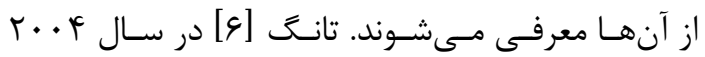

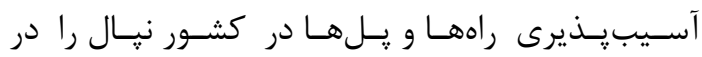

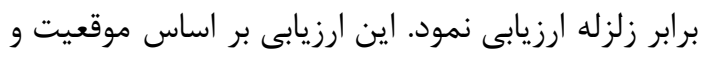

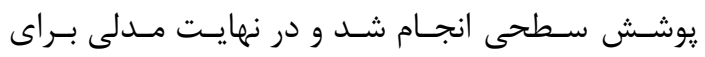

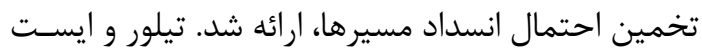

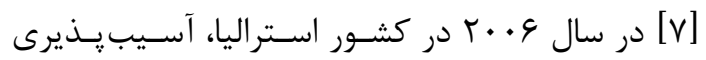

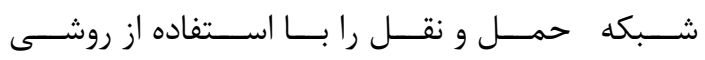
براى تشخيص نقاط بحرانى در زيرسـاختهـاى معـابر،

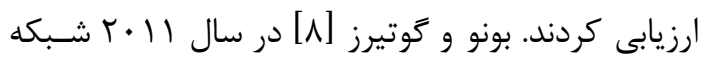

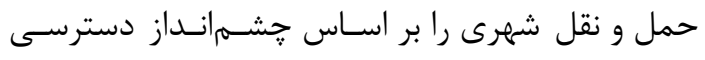

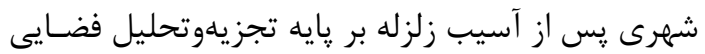
در محيط سيستمهــاى اطلاعـات مكـانى انجـام دادنـد.

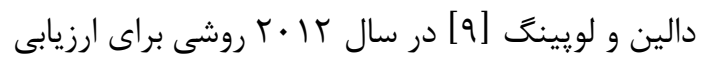

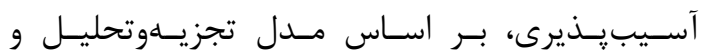

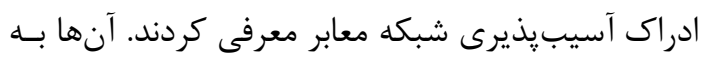

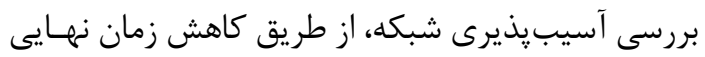

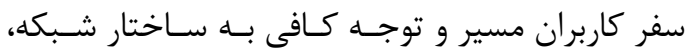

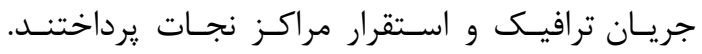

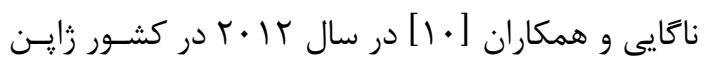

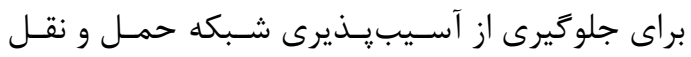

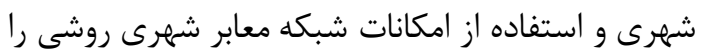

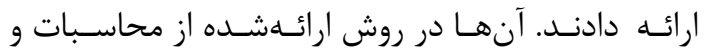

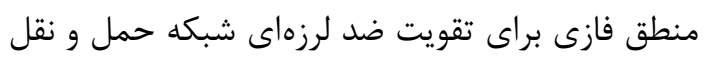

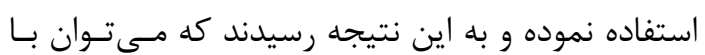

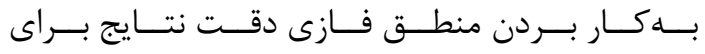

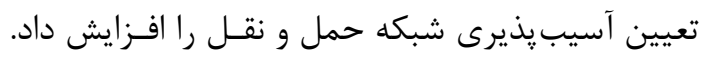

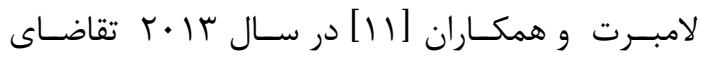
سيستم حمل و نقل و عملكرد سيستم را براى مديريت

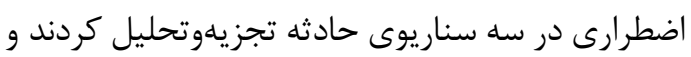

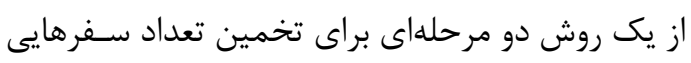
كه براى تخليه منطقه صورت مى كيرد با توجه به رفتئسار

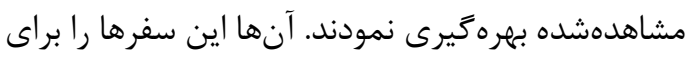

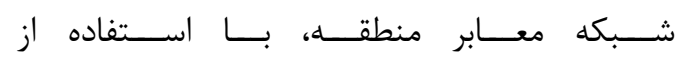


هر يك از يزوهش هاى ياد شده بر اساس زاويأُ نگرش به

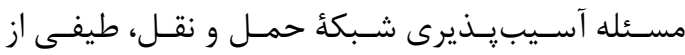
معيارها وشاخص هاى آسيب زّذيرى را ارائـهـ نمـوده انـد.

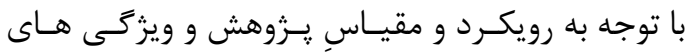

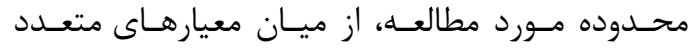

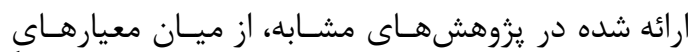
مندرج درجـدول ( (1)، معيـار عـرض مسـيرها بـهدليـل

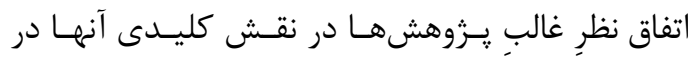
تعيين سطح آسيب پِيرى مسيرها، و معيارهاى فاصله از تاسيسات خطرناك، تعداد تقاطع ها و معيارهاى مربـوط مئي

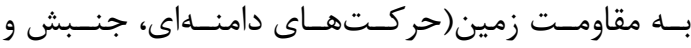

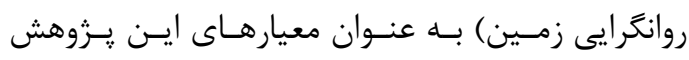
انتخاب زرديدهاند.
در اين مقاله براى تهيه نقشه آسيبِيذيرى شبكه حمـل

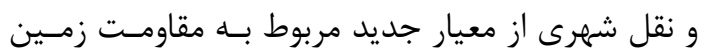
بستر شبكه حمل و نقل(حركتهاى دامنهاى، جنبش و

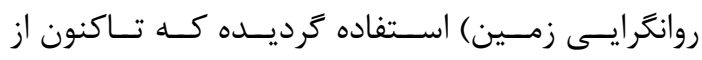

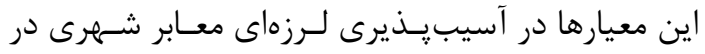

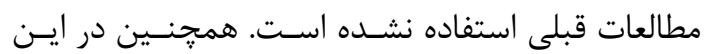
تحقيق براى تعيين مطلوبيـت و سـطح عملكـرد شــــه

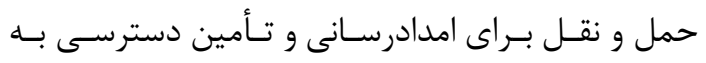

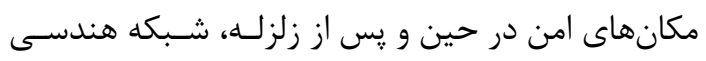
معابر طراحى و با در نظر گرفتن آسيبيذير بودن آنهـا

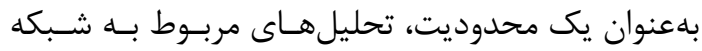
حمل و نقل شهرى مانند تعيين نزديكترين و امنترين مسير براى تخليه و نجات مصدومين انجام شد.

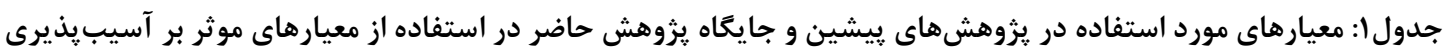
شبكه حمل و نقل

\begin{tabular}{|c|c|c|}
\hline يزوهشها & معيارهاى موثر بر آسيب يذيرى شبكه حمل و & $\hat{\mathfrak{s}}$ \\
\hline عزيزى و همافر، ناحايى و همكاران & شيب مسيرها & 1 \\
\hline |حدنزاد و همكاران، لامبرت و همكاران، بونو و گوتيرز & |رتفاع ساختمان هاى مشرف به مسيرها & r \\
\hline |حدنزاد و همكاران، تيلور و ايست & قدمت ساختمان هاى مشرف به مسيرها & r \\
\hline لويينغ، تانگ و همافر، نزاد اكبرى راورى و مجرد كاهانى، دالين و & |طول مسيرها & r \\
\hline نززاد اكبرى راورى و مجرد كاهانى، دالين و لويينگ، يزوهش حاضر & عرض مسيرها & $\Delta$ \\
\hline زنگنـه، لامبرت و همكاران، دالين و لويينگ، تانَ & تعداد يل ها & \& \\
\hline |حدنزاد و همكاران، ناكايى و همكاران، بونو و گوتيرز، تيلور و ايست & 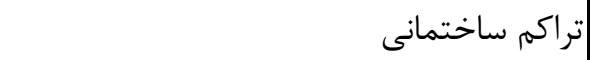 & V \\
\hline اد و همكاران، عزيزى و همافر & تراكم جمعيتى & $\wedge$ \\
\hline |ناكايى و همكاران ، تانت ،يزوهش حاضر & 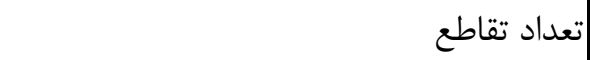 & 9 \\
\hline |ناعايى و همكاران ،يزوهش حاضر & فاصله از تاسيسات خطرناى شهرى & $1 \cdot$ \\
\hline 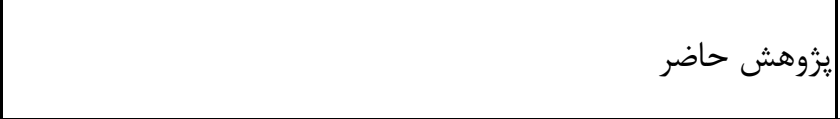 & جنيارهاى مقاومت زمين (حركتهاى دامنهاى، & 11 \\
\hline
\end{tabular}

و سيس به روش تحليل سلسله مراتبى وزن دهـى و در

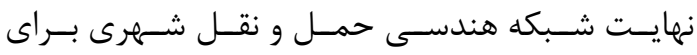

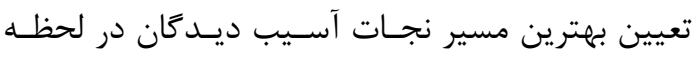

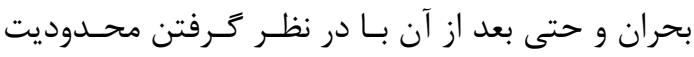

r- (- مبانى نظرى

در اين تحقيق ابتـدا بــر اسـاس روش دلفـى معيارهـاى

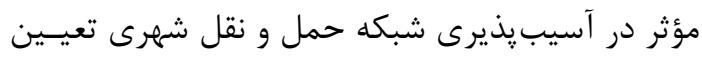


جند شاخصه مبتنى بر سيستم اطلاعـات مكــنى اسـت.

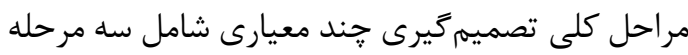

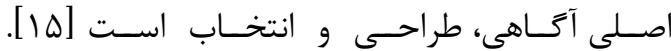

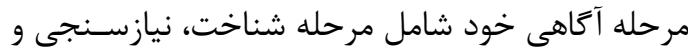
ساختاردهى مسئله است. در پايان اين مرحله معيارهاى تصميم كيرى استخراج و به عبارتى ساده ساختار سلسله دانه

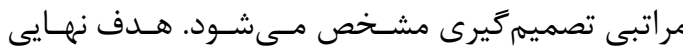

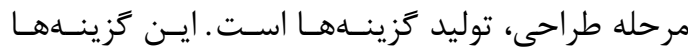
با توجه به هدف مسئله و قيود تعريف شده در مسئله از روى دادههاى موجود توليد مى گردند. در مرحله انتخاب

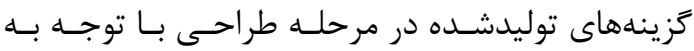

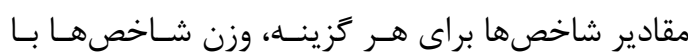

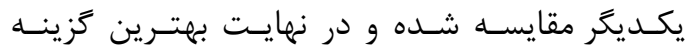

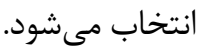

\section{r-Y - طراحى شبكه هندسى حمل و نقل شهرى} ايجاد شبكه هندسى حمل و نقل در زمينه قابليتهـاى تجزيهوتحليل شبكه در سيسـتمهــاى اطلاعـات مكـانى

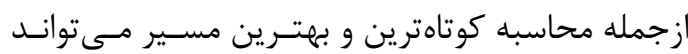

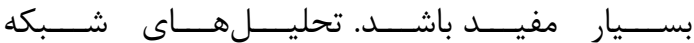

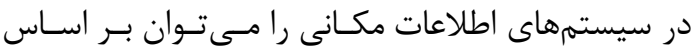

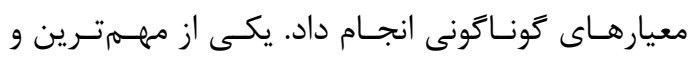
ير كاربردترين اين معيارها، معيار زمان سفراست. مـوارد

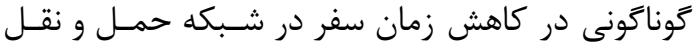

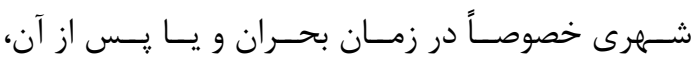

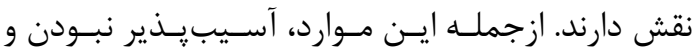
ايمن بودن مسير است. در حال حاضر اكثر سـامانههـاى

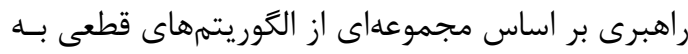
محاسبه مسير بهيينه مىيردازند؛ بدين ترتيب كه در ايـن

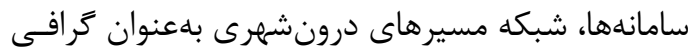

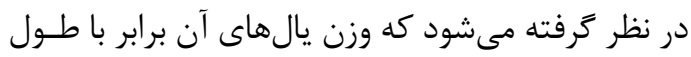

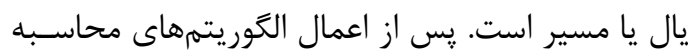
كوتاهترين مسير بر روى اين خـراف، مسـير بهينـه و ويـا

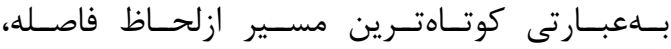

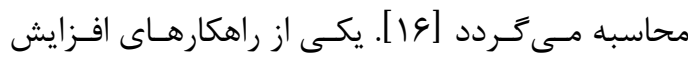

معابر آسيب يذير، در محيط سيستم اطلاعـات مكـانى،

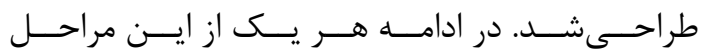
تشريح خواهد شد.

\section{ץ-1- مدل آسيبيذيرى شبكه حمل و نقل شهرى} تصميمگيرى فرايندى است كه شامل مراحـل مختلفـى

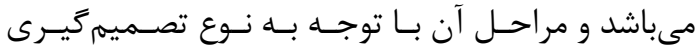

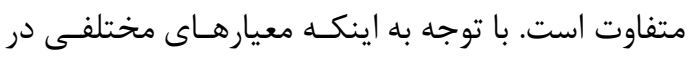

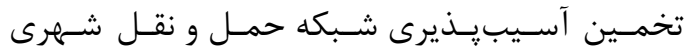

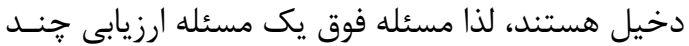
معياره' بوده كه براى مدلسازى آسيب يذيرى ابتدا بايسـ

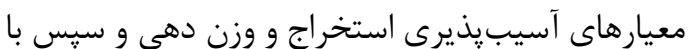

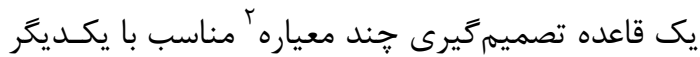

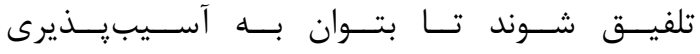
موردنظر دست يافت. مدل هاى جند معياره خـود انـواع مختلفى دارند كه در يك طبقهبندى كلى مى توان آنها

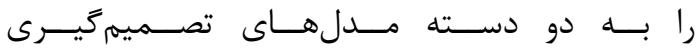

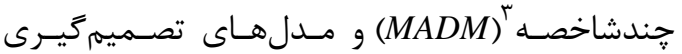
جندهدفه جندهدفه، קندين هدف بلطور همزمـان جهـت بهينـهـ

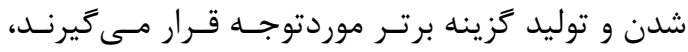

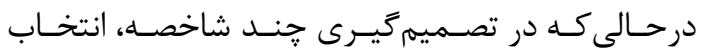

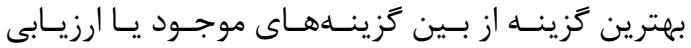
كزينهها (مرتب كردن كزينهها) مـدنظر اسـت. تفــاوت

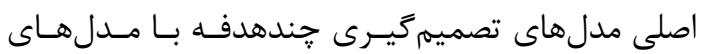

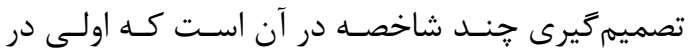
فضـاى تصـميميَيـرى زيوسـته و دومسى در فضـاى تصميمكيرى گسسته تعريف مىشوند. با توجه به اينكه

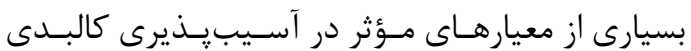
ماهيت مكانى دارند، مدلى كه براى تعيين آسيبيذيرى

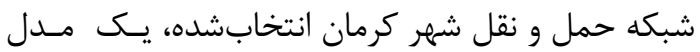

${ }^{1}$-Multi-Criteria Evaluation

${ }^{2}$ Multi-Criteria Decision Rule

${ }^{3}$ Multi Attribute Decision Model

${ }^{4}$ Multi Objective Decision Model 
بسيارى حتى احتمال زلزلهاى با شدت V ريشـتر رانيـز

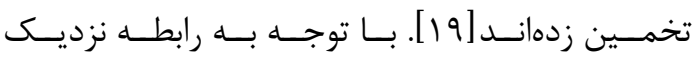

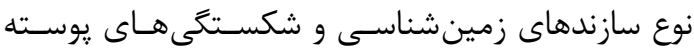

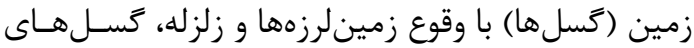

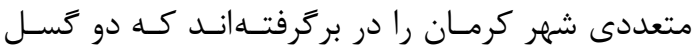

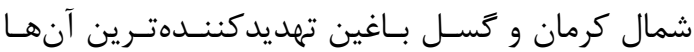

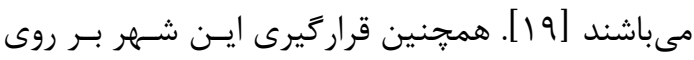

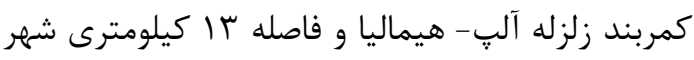

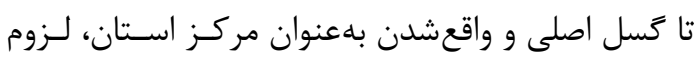

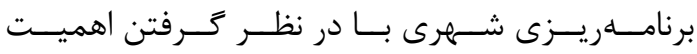

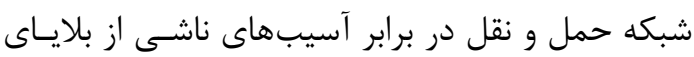

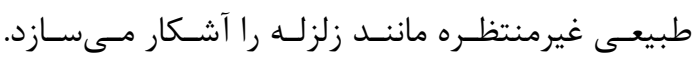

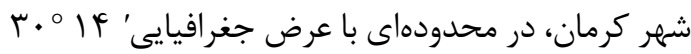

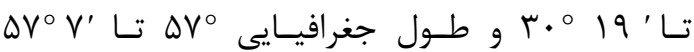
شمالى واقع شده است. جمعيت شـهر كرمـان بــيش از

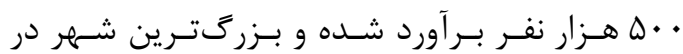
جنوب شرقى كشور است. اين شهر با ارتفـاع . . IV تـا

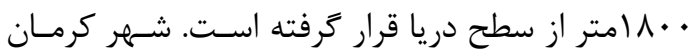

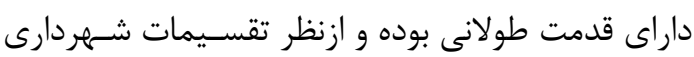
داراى جهار منطقه شهرى است شكل (1).

\section{P - 1وش تحقيق}

در اين تحقيق تلاش شده است تـا در قالـب معيارهـاى شهرسازى با توجه به مطالعات بيشـين در ايـن زمينـه،

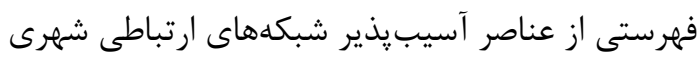

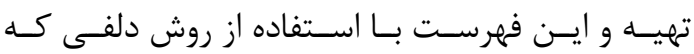
نظرخواهى از خبركان آشنا به موضـوع استـ، نهـايى و

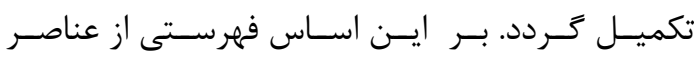

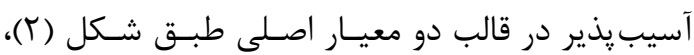

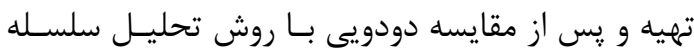

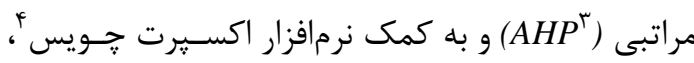

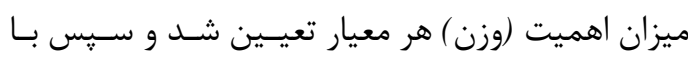

\footnotetext{
${ }^{3}$ Analytical Hierarchy Process

${ }^{4}$ Expert Choice
}

اعتبار و اعتماديذيرى مسير بهينه محاسبهشـده توسـط

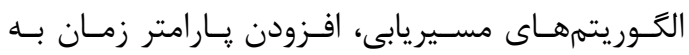
محاسبات است كه موضـوع بحـث مسـيريابى زمانمنــد

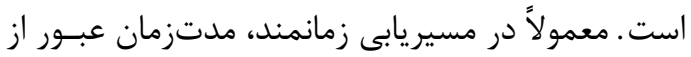

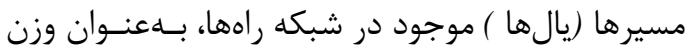
آنها در نظر عرفته مىشود [IV] شبكه هندسى مجموعهاى از عوارض است كه با عوارض

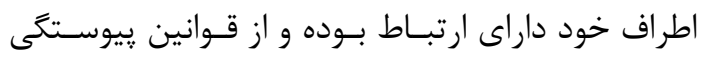

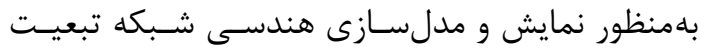

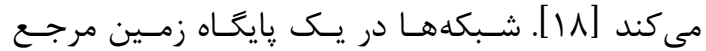

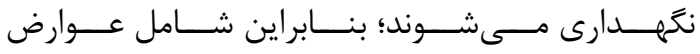

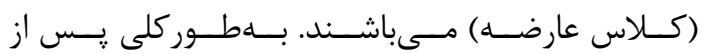

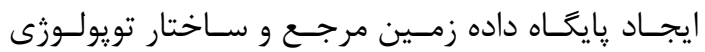
مراحل زير بايد انجام شود تا يك شبكه هندسى حمل و نقل شهرى طراحى گردد:

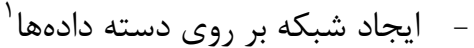

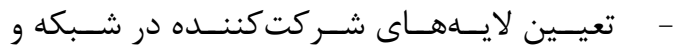
ايجاد قوانين ارتباطات - لحاظ كردن قوانين رفتوآمد در شبكه - مشـخص نمــودن فيلـدهاى كليـدى و مــؤثر در تحليل شبكه و رفع خطاهاى رخ داده در شبكه

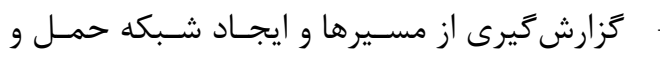

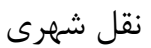

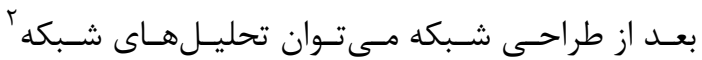
مانند تعيين كوتاهترين و بهترين مسير را انجام داد.

r- بن - منطه مورد مطالعه شهر كرمان در دشتى نسبتاً وسيع قرارگرفته كه ازنظـر جمعيتى در رده شهرهاى بالاى پانصد هزار نفر كشور و

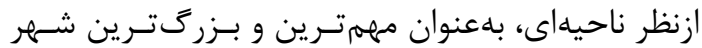
جنوب شرق، عملكردى فرا منطقهاى دارد. كارشناسـان بـان بـان متعددى زلزله خيزى شهر كرمان را بررسى نمودهاند كه

\footnotetext{
${ }^{1}$ Network Dataset

${ }^{2}$ Network Analyes
} 


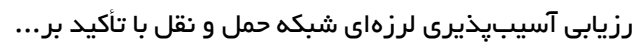

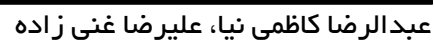

استفاده از محيط GIS، نقشهُ آسيبذيذيرى شبكه حمـل منطقه موردنظر، با توجه به آسيبذيذيرى هـر مسـير در

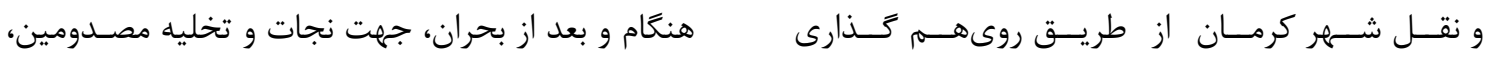

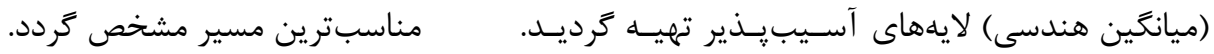

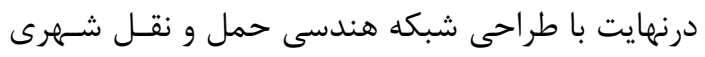
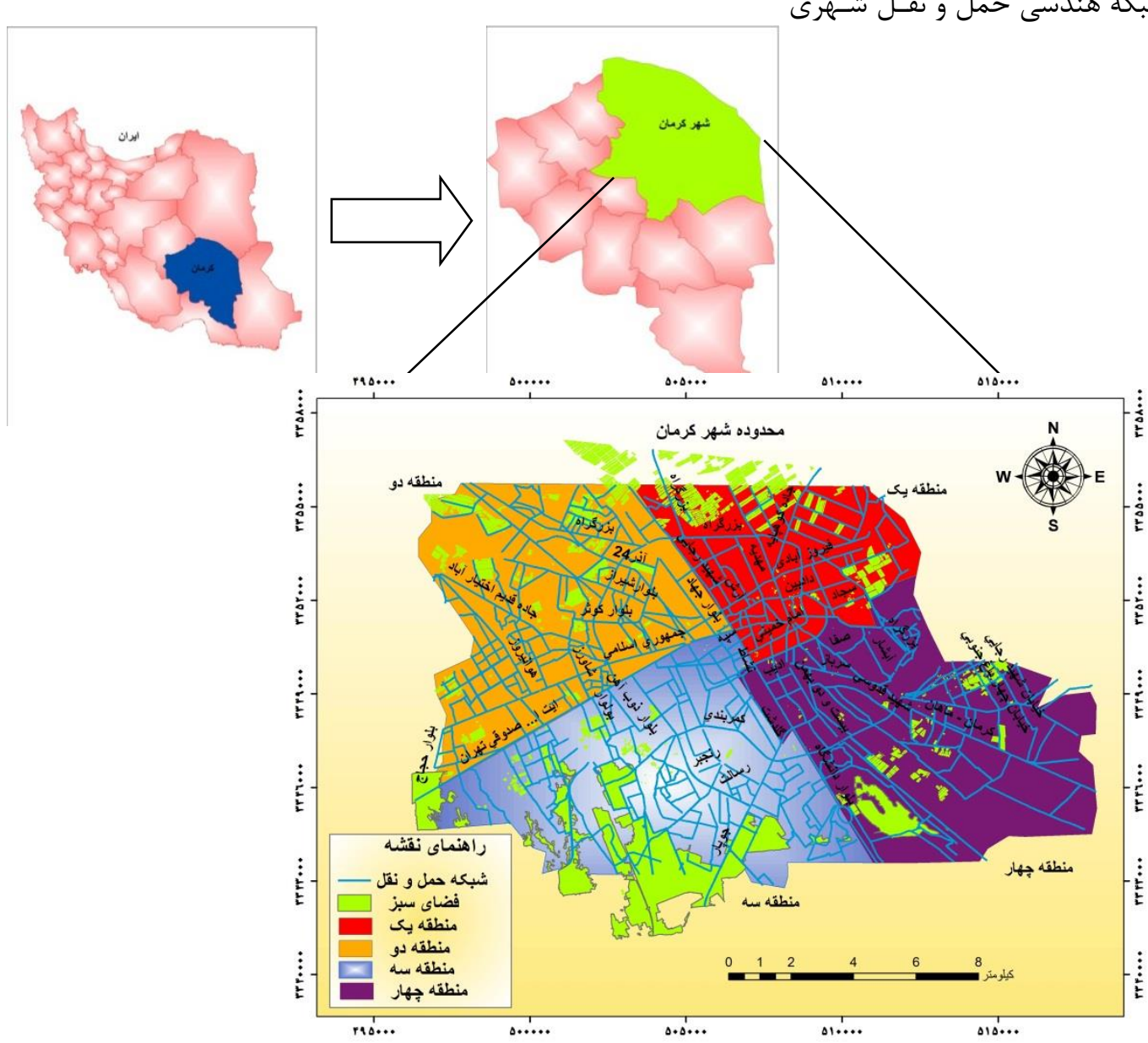

شكل I : موقعيت منطقه موردمطالعه

بلهروز رسانى ترديـــه اسـت. ايسن نقشـهـهـا در محسيط

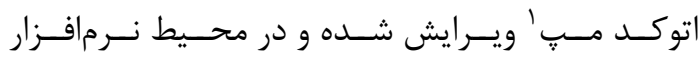

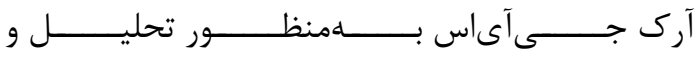

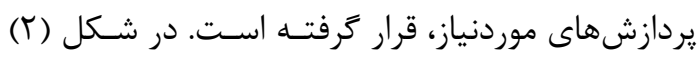
مراحل انجام اين يُوهش ارائه كرديده است.

\footnotetext{
${ }^{1}$ AutoCAD Map
}

رويكرد حاكم بر يزوهش توصيفى - تحليلى و نــوع آن

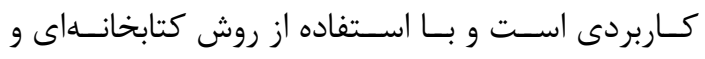

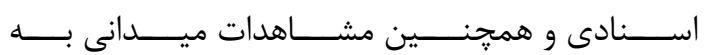
انجام اين تحقيق اقدام شده است. به اينصورت كـهـ بـا

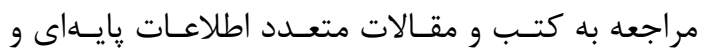

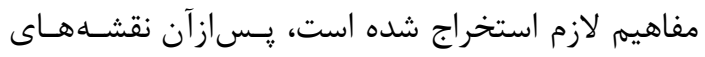

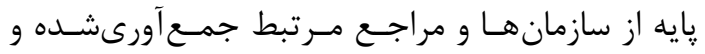

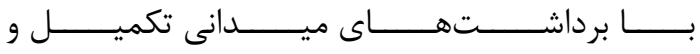




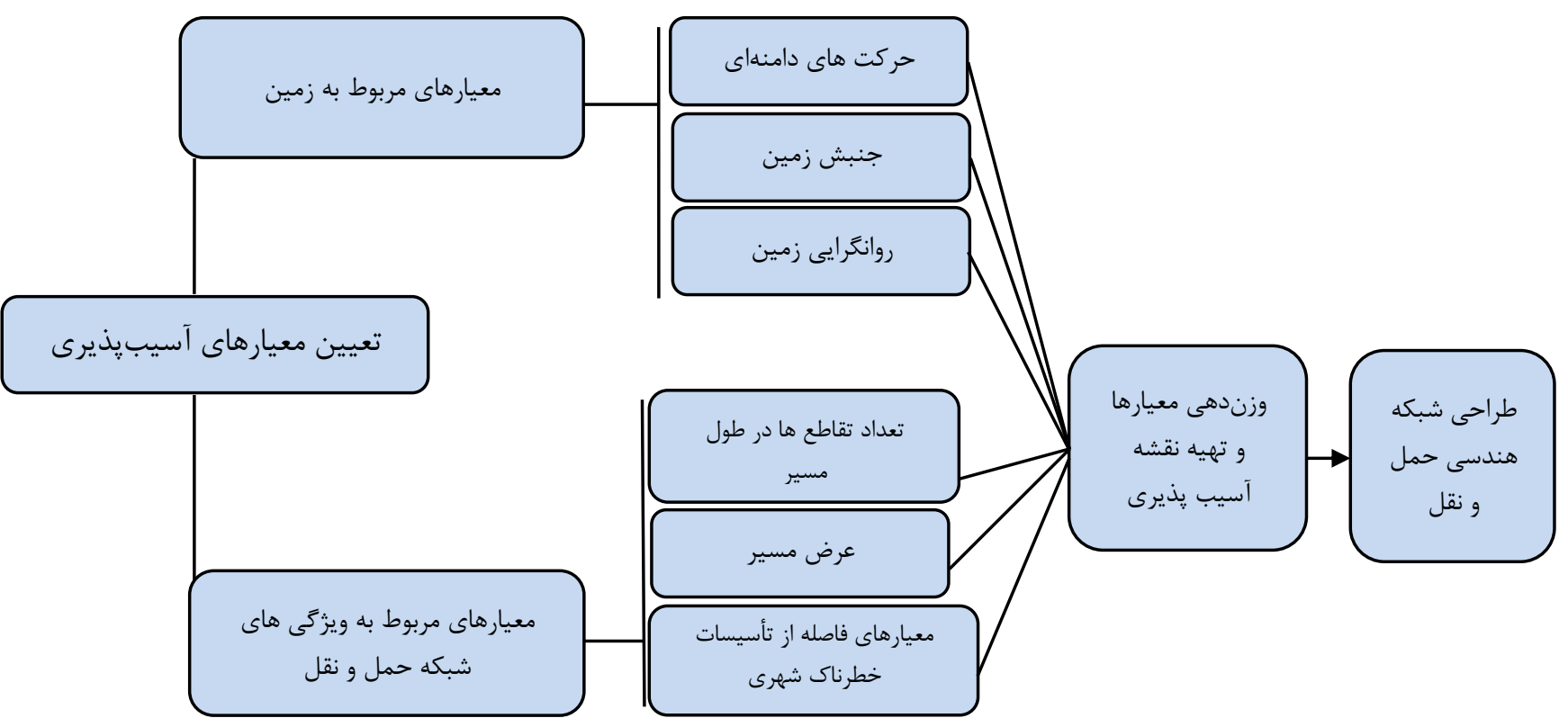

شكل r: روش و مراحل كلى انجام تحقيق

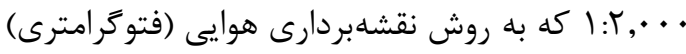

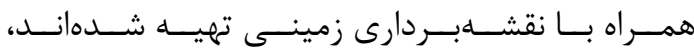
استفاده گرديد. براى تهيه نقشه آسيب يذيرى شبكه حمل و نقل شهرى

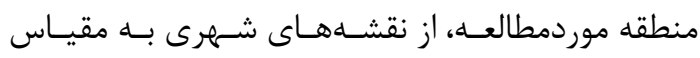
جدول r: دادههاى مورداستفاده در تحقيق.

\begin{tabular}{|c|c|c|c|c|}
\hline منبع & سال تهيه & مقياس & داده (نقشهها) & رديف \\
\hline سازمان نقشهبردارى كشور & ITNV & $1: \omega, \cdots$ & عكس هاى هوايى & 1 \\
\hline شهردارى كرمان & ITNV & $1: r, \cdots$ & نقشه معابر شهرى & $r$ \\
\hline شهردارى كرمان & ITNV & $1: r, \cdots$ & نقشه كاربرى اراضى شهرى & r \\
\hline
\end{tabular}
شامل توليد ماتريس مقايسه زوجـى معيارهـا، محاسـبه

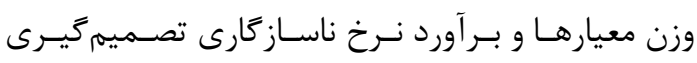
(جهت اطمينان حاصل كردن از سـازكارى مقايسـهــا) مىباشند. عناصر ماتريس مقايسه زوجى، اهميت نسـبى

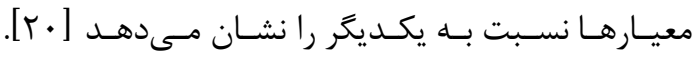

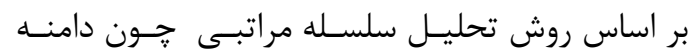

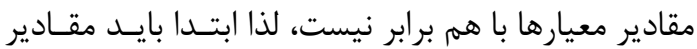
معيارها نرمال شوند؛ بنابراين وزن نهايـى نتـايج مقايسـهـ

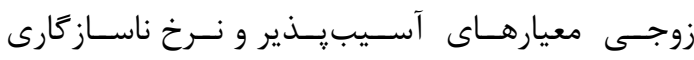

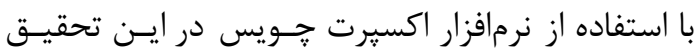

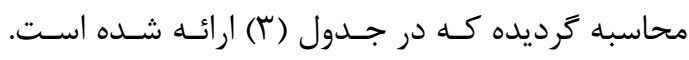

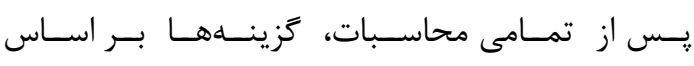

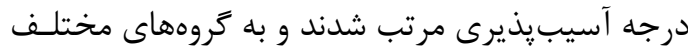

P-r-r - تهيه نقشه آسيب يذيرى شبكه حمل و نقل منطقه در برابر زلزله

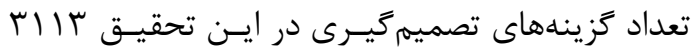
مسير بود. در اين مرحله طبقهبندى مسيرهاى ارتبـاطى لمهي

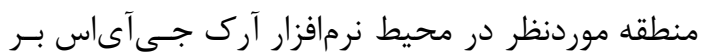
روى لايـهـ شـبكه حمـل و نقــل انجـام شـد. طبـق نظرات نهايى كارشناسى با روش دلفى طبق شـكل (r)

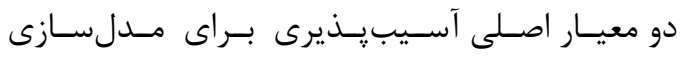

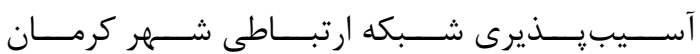
انتخاب گرديده و بر اساس جداول مربوطه وزنهاى هـر معيار تعيين شده است. براى وزن دهى از روش تحليـل

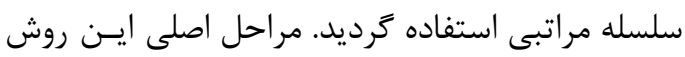


رزيابى آسيبيذيرى لرزاى شبكه حمل و نقل با تأكيد بر...

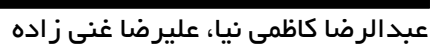

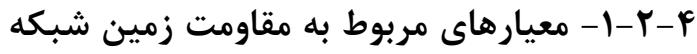

تقسيم گرديدند. در ايـن تحقيـق شـبكه حمـل و نقــل حمل و نقل منطقه موردمطالعه

معيار هـاى مقاومست خـاك بسـتر شـبكه حمـل و نقـل

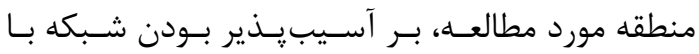

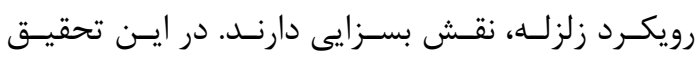

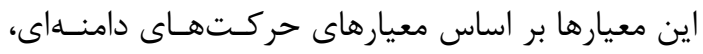

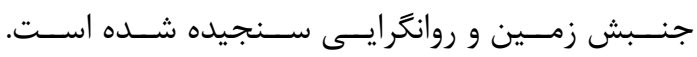
بر اساس روش دلفى و تحليل سلسله مراتبى معيارهـاى زئس

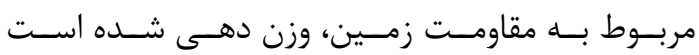
جدول (f). سيس نقشه آسيب يـذيرى شـبكه حمـل و نقل منطقه مورد نظر در محيط سيستم اطلاعات مكانى با توجه به وزن هر معيار، تهيه گرديد. منوريط

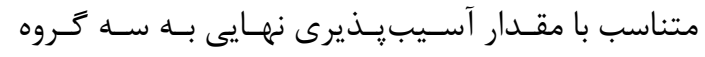
آسيب پذيرى كم، متوسط و زياد طبقهبندى شدهاند. جدول r: وزن نهايى معيارهاى مؤثر در آسيب يذير

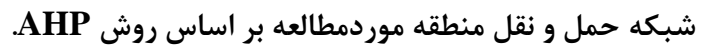

\begin{tabular}{|c|c|c|}
\hline ناسازًَارى & $\begin{array}{c}\text { وزن دهى بر اساس } \\
\text { AHP روش }\end{array}$ & معيار \\
\hline \multirow{6}{*}{$\cdot .9 \mathrm{~V}$} & . & تعداد تقاطعها \\
\hline & $\cdot \mid 111$ & عرض مسيرها \\
\hline & $\cdot \| F$ & خاصــله از تأسيســــات \\
\hline &., 190 & روانگر ايى زمين \\
\hline & $\cdot r \cdot v$ & جنبش زمين \\
\hline & $\cdot \cdot \Lambda f$ & تركين كتهــاى دامنــــهاى \\
\hline
\end{tabular}

جدول f: معيار هاى مربوط مقاومت زمين شبكه ارتباطى و وزنهاى مربوطه

\begin{tabular}{|c|c|c|c|}
\hline وزن آسيب يذيرى & طبقه & معيار & رديف \\
\hline 1 & كسيختخى كم (شيب كمتر از ه درصد) & \multirow{3}{*}{ حركتهاى دامنهاى بر اساس شيب } & \multirow{3}{*}{1} \\
\hline r & كسيختخى متوسط (شيب ه تا • ا درصد) & & \\
\hline r & كسيختخى زياد (شيب بيش از • درصد) & & \\
\hline$r$ & |عمق كمتر از · ا متر & \multirow{2}{*}{ بر اساس عمق آب زيرزمينى و زمين ماسيى } & \multirow[b]{2}{*}{$r$} \\
\hline 1 & | عمق بيشتر از • ا متر & & \\
\hline 1 & 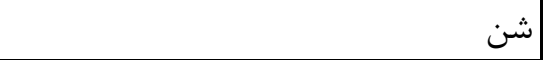 & \multirow{3}{*}{ جنبش زمينبر اساس بافت خاك و } & \multirow{3}{*}{ r } \\
\hline r & رس رس & & \\
\hline r & |ماسه & & \\
\hline
\end{tabular}

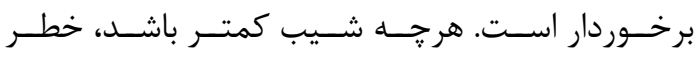

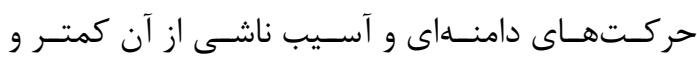

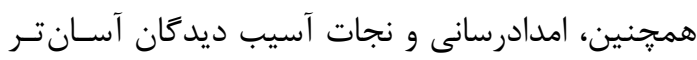
خواهد بود. در اين تحقيق براى تهيه نقشه آسيب

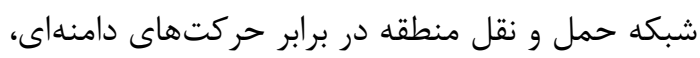

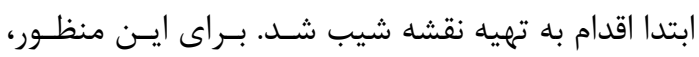

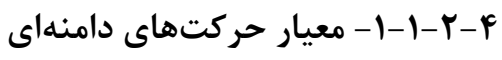
يكى از جنبههاى رايج آسيب لرزماى، خطر حركتهـاى

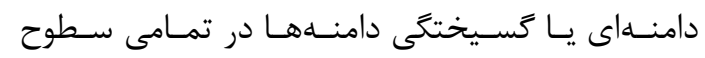

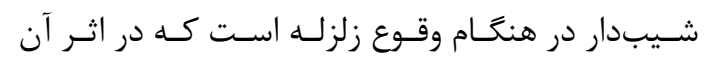
آسـيب وارد مسىشـود [19]. شـيب زمـين در كـارايى زيى

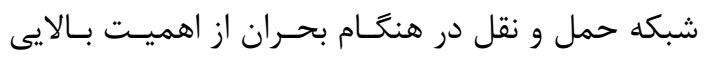


كمتر باشد آسيبيذيرى مسير كمتر مىشود بـر اسـاس

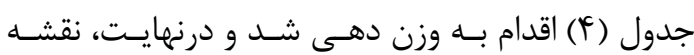

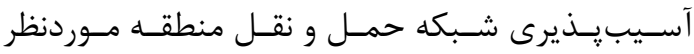

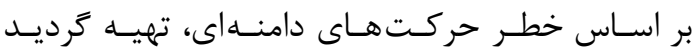

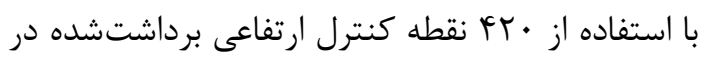

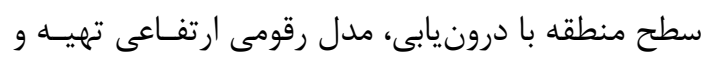

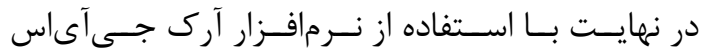

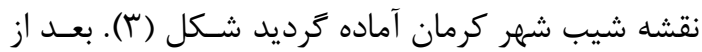

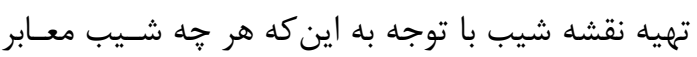

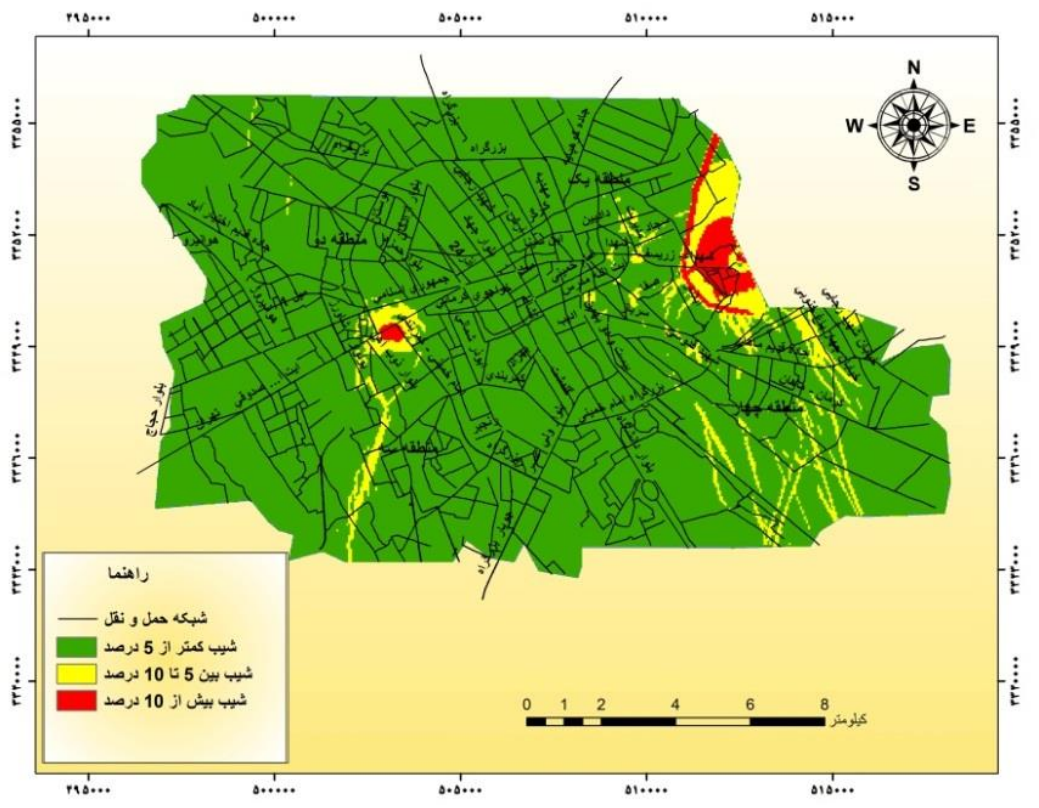

شكل r: نقشه شيب منطقه موردمطالعه

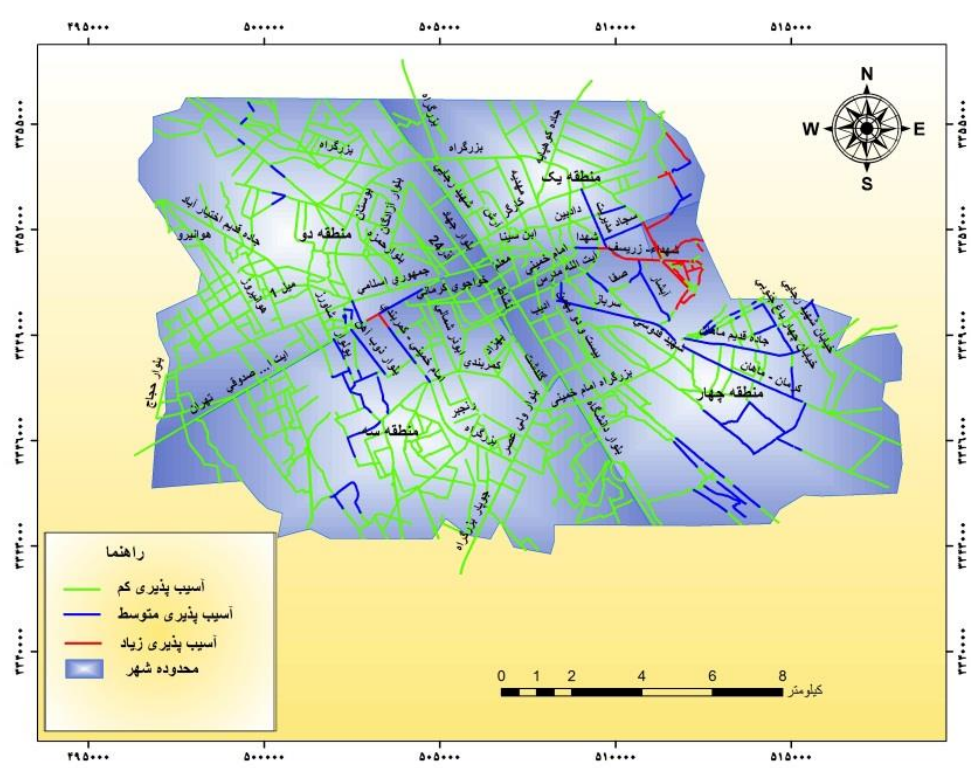

شكل f: نقشه آسيب يذيرى شبكه حمل و نقل منطقه موردمطالعه بر اساس خطر حركتهاى دامنهاى.

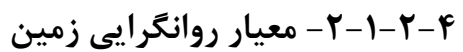

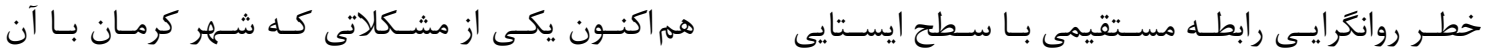


نقشـهـ زمــينشناسـى منطقـهـ اسـتفاده گرديــده اسـت.

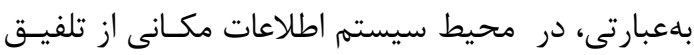
نقشه عمق آب زيرزمينى و نوع رسوبات زمــين منطقـه،

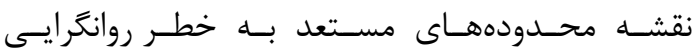

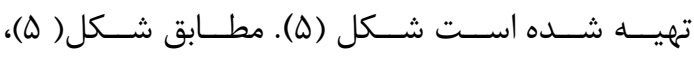
محسـدودههــايى از شــبكه حمــل و نقــل منطقــه كــه

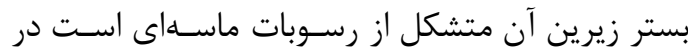
صورت بالا بـودن سـطح آبهـاى زيرزمينـى، يتانسـيل

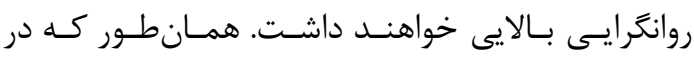
شكل (ه) مشاهده مى شود، فقط محدوده بافت قـديم

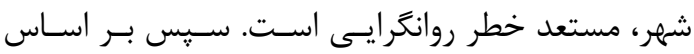

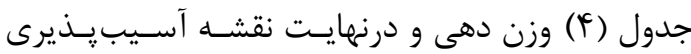
شبكه حمل و نقل بر اساس معيار مـوردنظر تهيـهـ شـد وند

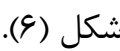

مواجه اسـت، سـطح بـالاى آبهـاى زيرزمينـى اسـت.

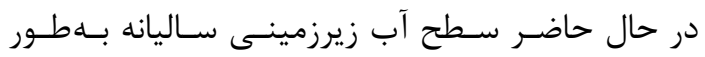
متوسط حدود نيم متر بالا مى آيد كـه دليـل آن تغذيـهـ آبهاى زيرزمينى در اثر ورود فاضلاب شهرى است. آر در ناحيهاى سطح آبهاى زيرزمينى بالا باشد، رسـوبات

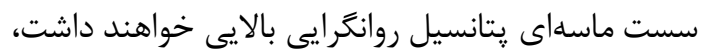

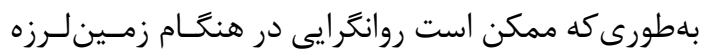
موجب آسيب به ساختمانهاى مجـاور، شـبكه حمـل و و

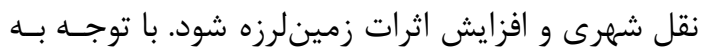

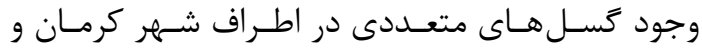

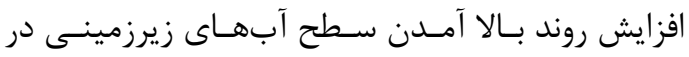

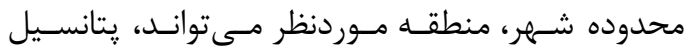

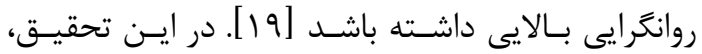
براى تهيه نقشه آسيب يذيرى شبكه حمل و نقل منطقه

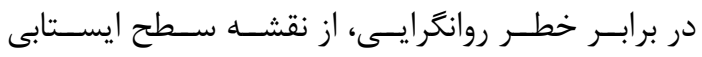
آبهاى زيرزمينى سازمان آب منطقهاى استان كرمان و

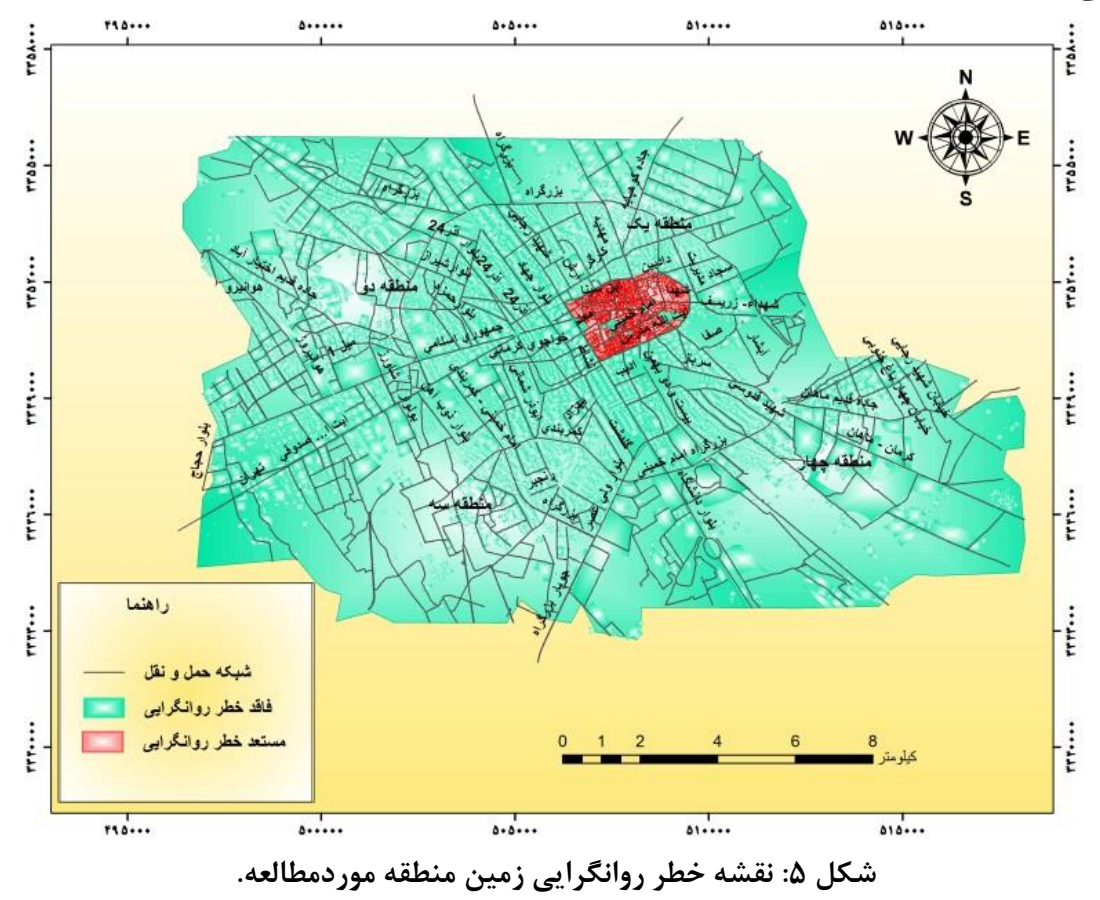




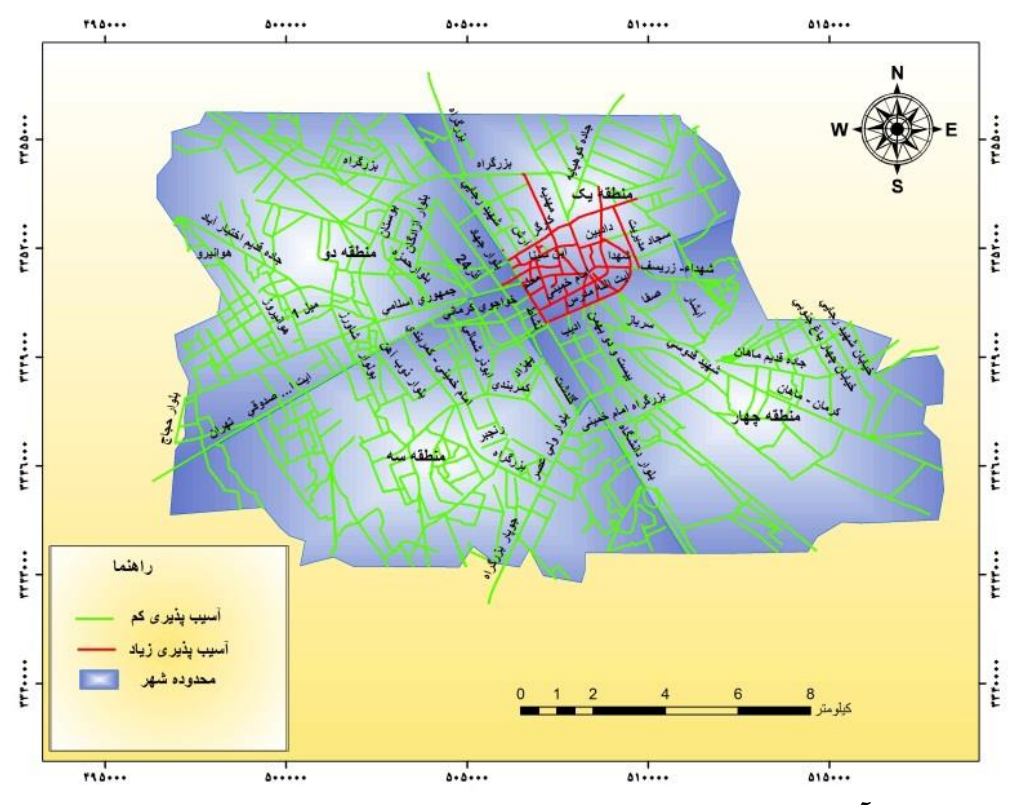

شكل \&: نقشه آسيب يذيرى شبكه حمل و نقل منطقه موردمطالعه بر اساس خطر روانگرايى.

تقويست مسى كنـــد كـه تـابع ويزَّى هــاى دينـاميكى

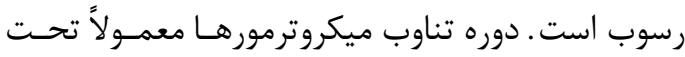

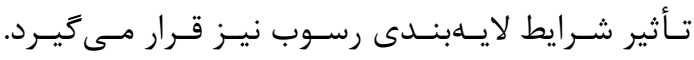

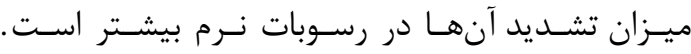
باطورى كه در خاكهاى ريزدانه مانند رسها، بيشـتر از

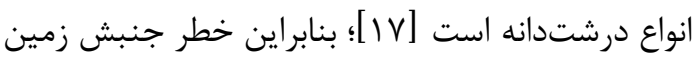
ارتباط مستقيم با رسوبات زيرساختى مسيرهاى حمل و وراني

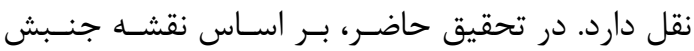

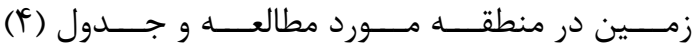
نقشه آسيبــــيرى شـبكه حمـل و نقـل شهـر كرمـان

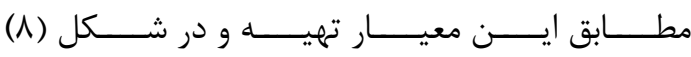
ارائه كرديده است.

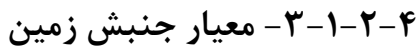

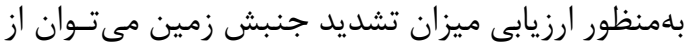

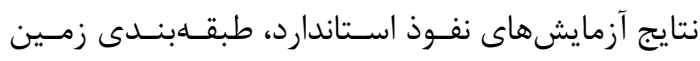

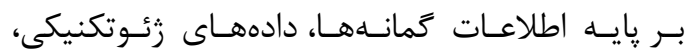
سنجشهاى ميكروترمورى و يا سرعت موج در خـاك و رسوب اسـتفاده كـرد. حسـنزاده و همكـاران در سـال

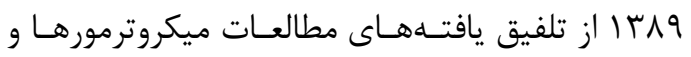
طبقابندى بر پايه اطلاعات كَمانههـا، اسـتفاده نمـوده و

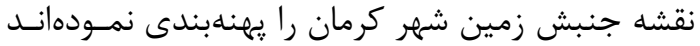
شكل (V) . ميكروترمورها لرزشهاى بسيار ضعيف دائمى

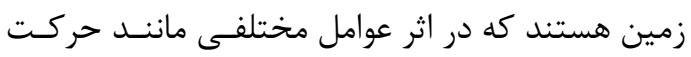

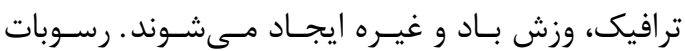

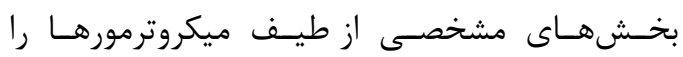


رزيابى آسيبيذيرى لرزهاى شبكه حمل و نقل با تأكيد بر...

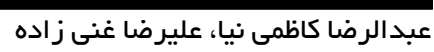
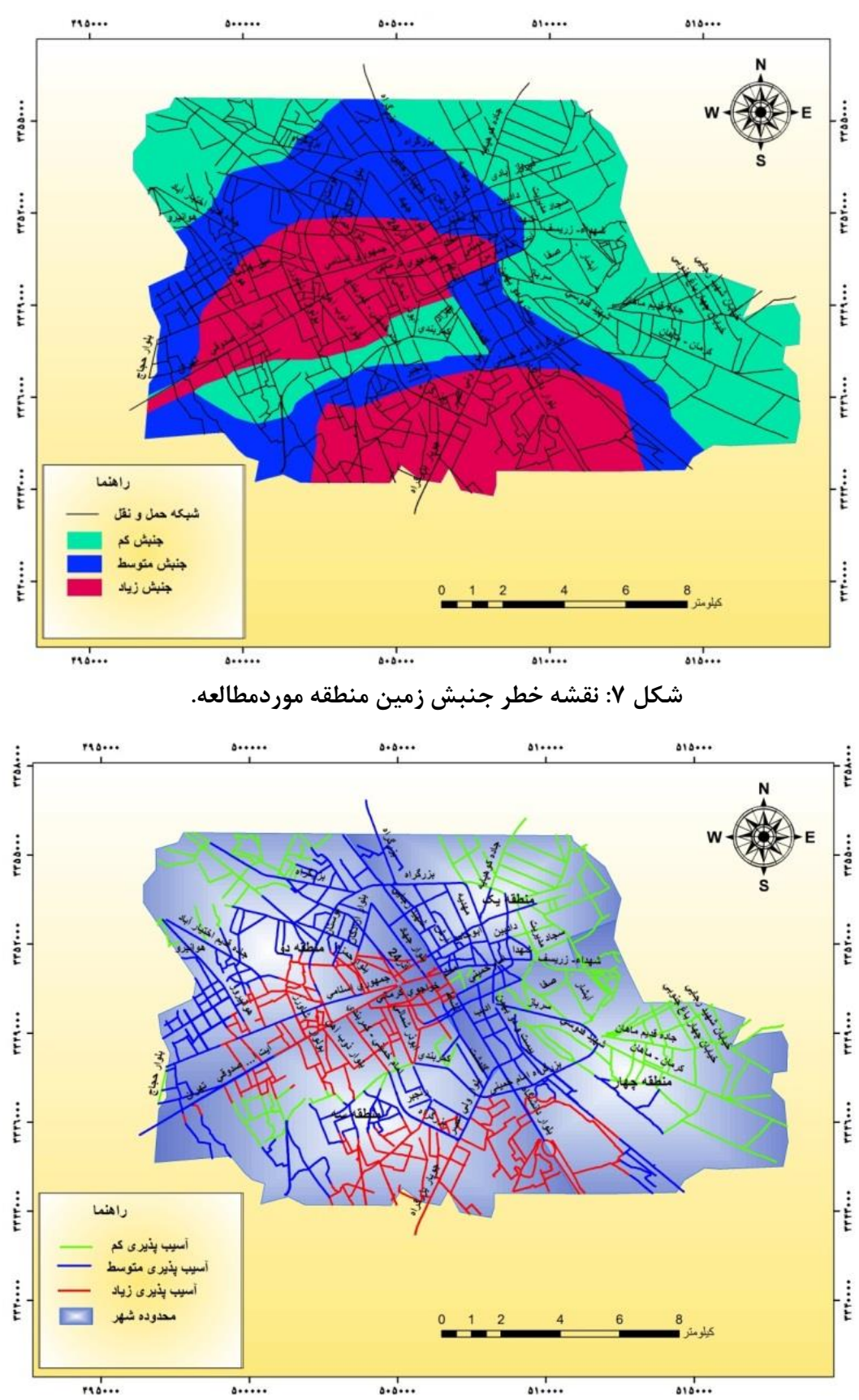

شكل ^: نقشه آسيب يذيرى شبكه حمل و نقل منطقه موردمطالعه بر اساس خطر جنبش زمين.

براى تهيه نقشه نهايى آسيبذيذيرى بـا دقـت بيشـتر، از

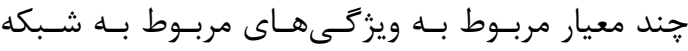

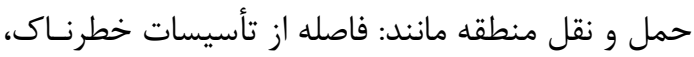
تعداد تقاطعها، طول، عرض مسيرهاى موجود در شبكه

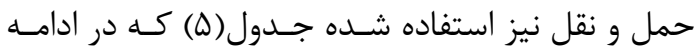
به معرفى آنها برداخته خواهد شد.

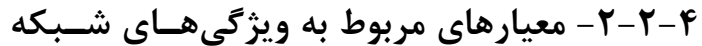
حمل و نقل منطقه موردمطالعه

هس از تعيين آسيبذيذيرى شبكه حمل و نقـل منطقـهـ

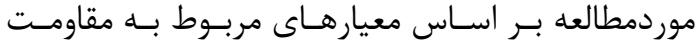

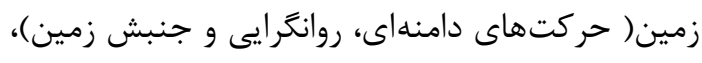


جدول ه: معيارهاى مربوط شبكه حمل و نقل و وزنهاى مربوطه

\begin{tabular}{|c|c|c|}
\hline هيب هيذيرى & طبقه & معيار \\
\hline 1 & |بيشـاطع (آسيبـيذيرى كم) & \multirow{3}{*}{ طعداد تقاطعها در مسير شبكه } \\
\hline r & 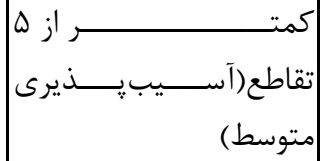 & \\
\hline r & زياد) & \\
\hline 1 & بيش از • •ه متر & \multirow{3}{*}{ عرض مسيرها } \\
\hline r & |•- • † متر & \\
\hline r & كمتر از • זمتر & \\
\hline 1 & بيش از +..1 متر & \multirow{3}{*}{ فأسيسه مسيرهات از } \\
\hline r & بين •.ه تا +..1 متر & \\
\hline r & كمتر از +.•ه متر & \\
\hline
\end{tabular}

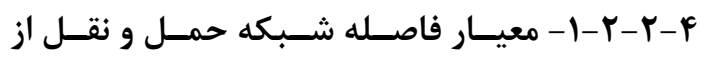
تأسيسات خطرناك شهرى

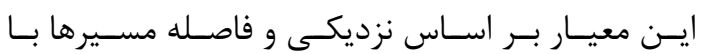

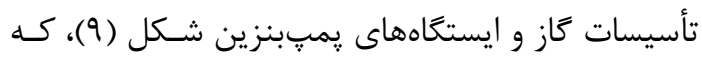

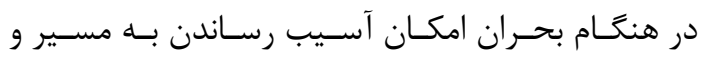

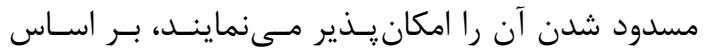

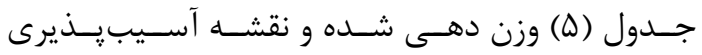
شبكه حمل و نقل تهيه شد شكل ( • (1).

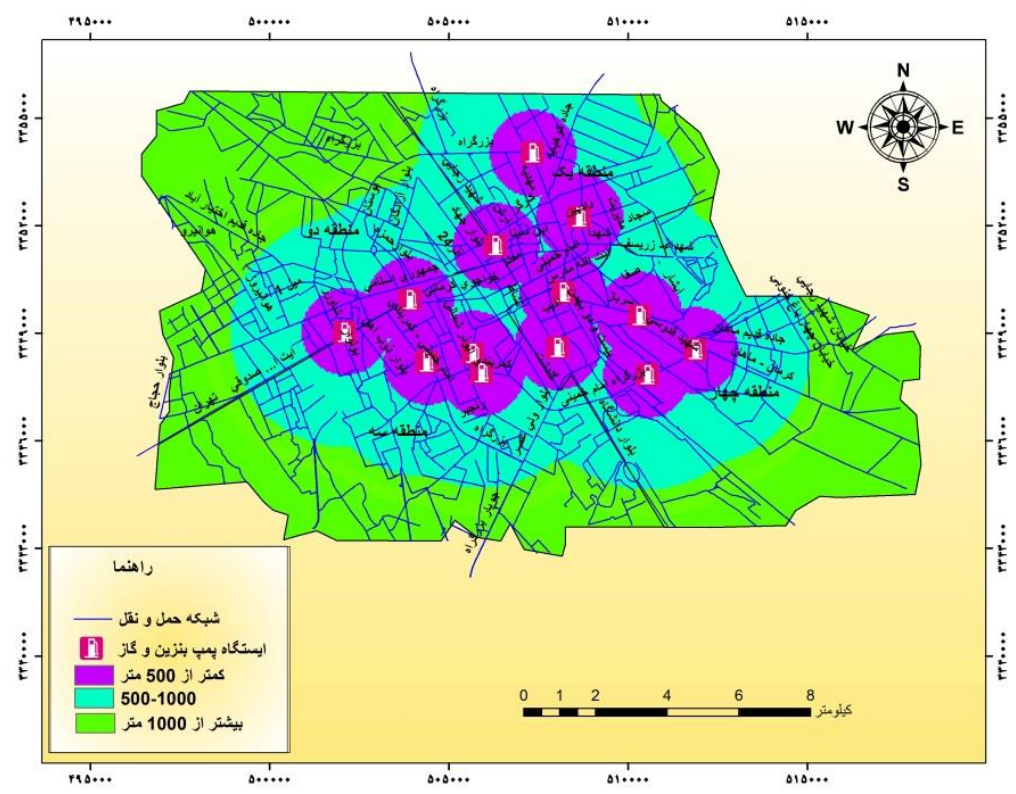

شكل 9: موقعيت و فاصله يراكندكى تأسيسات ايستكاههاى گَاز و يمٍٍبنزين نسبت به شبكه حمل و نقل در منطقه موردمطالعه. 
رزيابى آسيبيذيرى لرزهاى شبكه حمل و نقل با تأكيد بر....

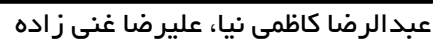

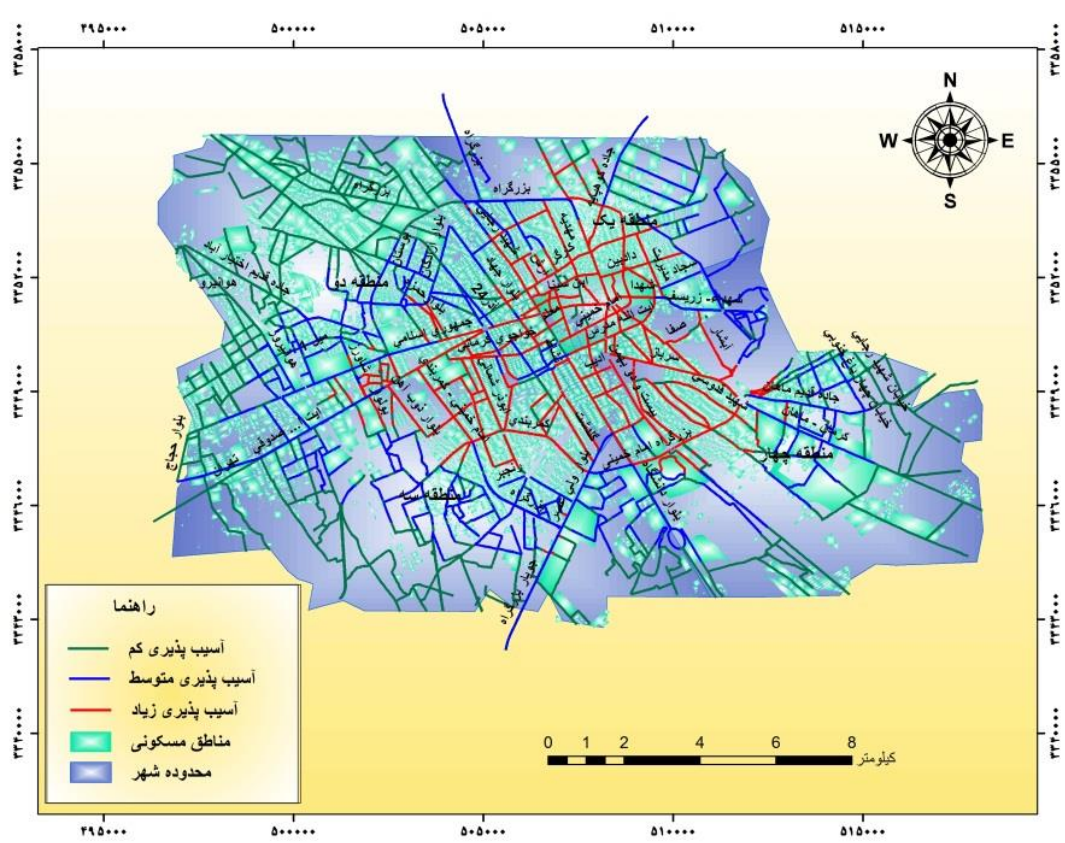

شكل •1 : نقشه آسيب يذيرى شبكه حمل و نقل منطقه موردمطالعه بر اساس فاصله از ايستخاههاى كاز و يمِبنزين.

آسيبديده بيشتر مىشود[اr|]. در ايـن تحقيـق بـراى

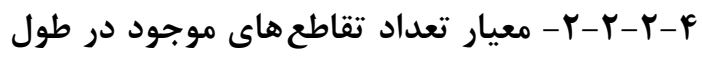

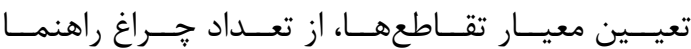

مسيرهاى شبكه حمل و نقل

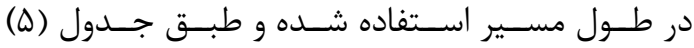

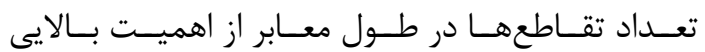

امتياز دهى كرديد شكل (1) - (1).

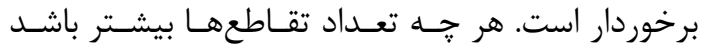

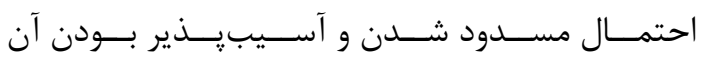

كاهشيافته و كزينههاى دسترسى براى خروج از مسـير

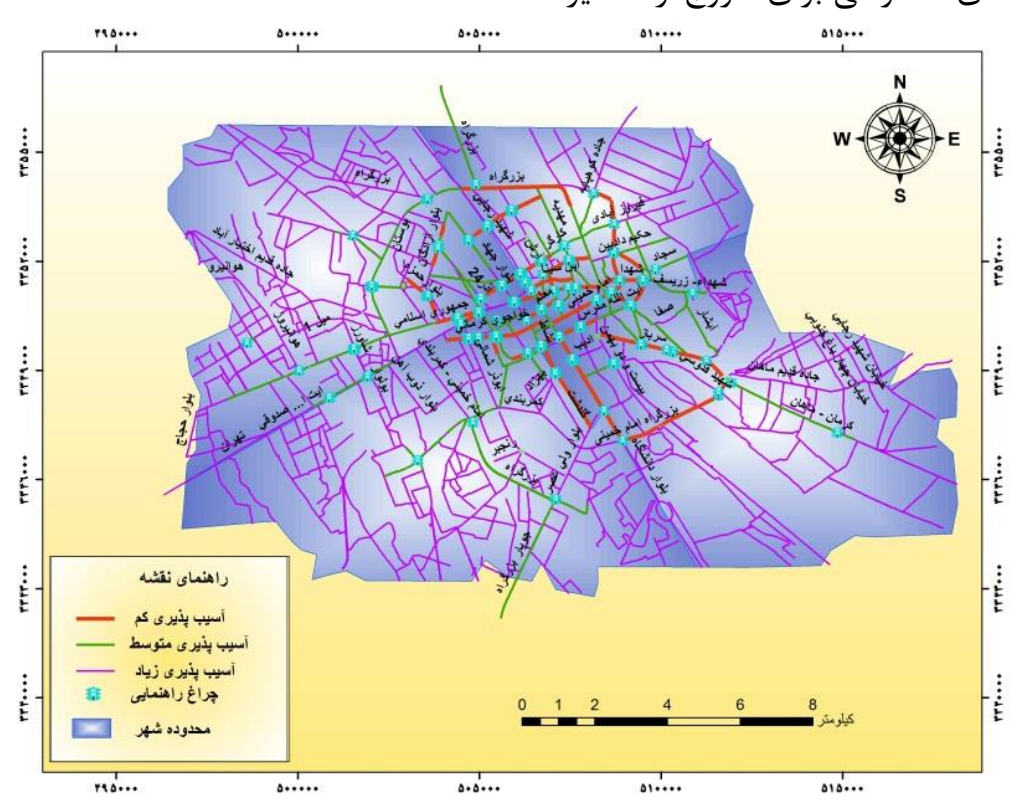

شكل / / نقشه آسيب يذيرى شبكه حمل و نقل منطقه موردمطالعه بر اساس تعداد تقاطعها. 


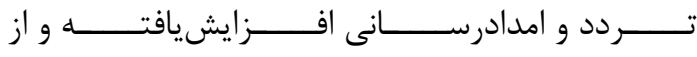

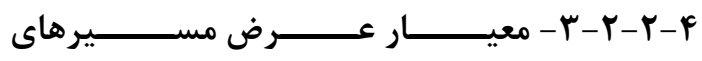

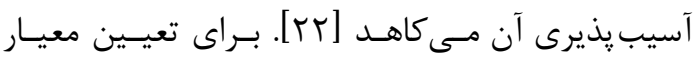

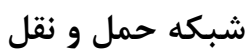

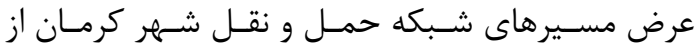

در زمينه كارايى شبكههاى حمل و ونقل و دسترسى درى در

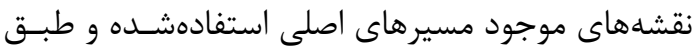

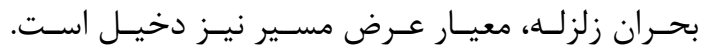

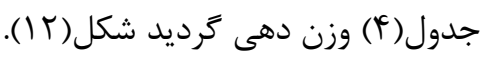

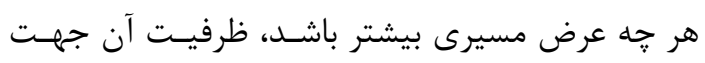

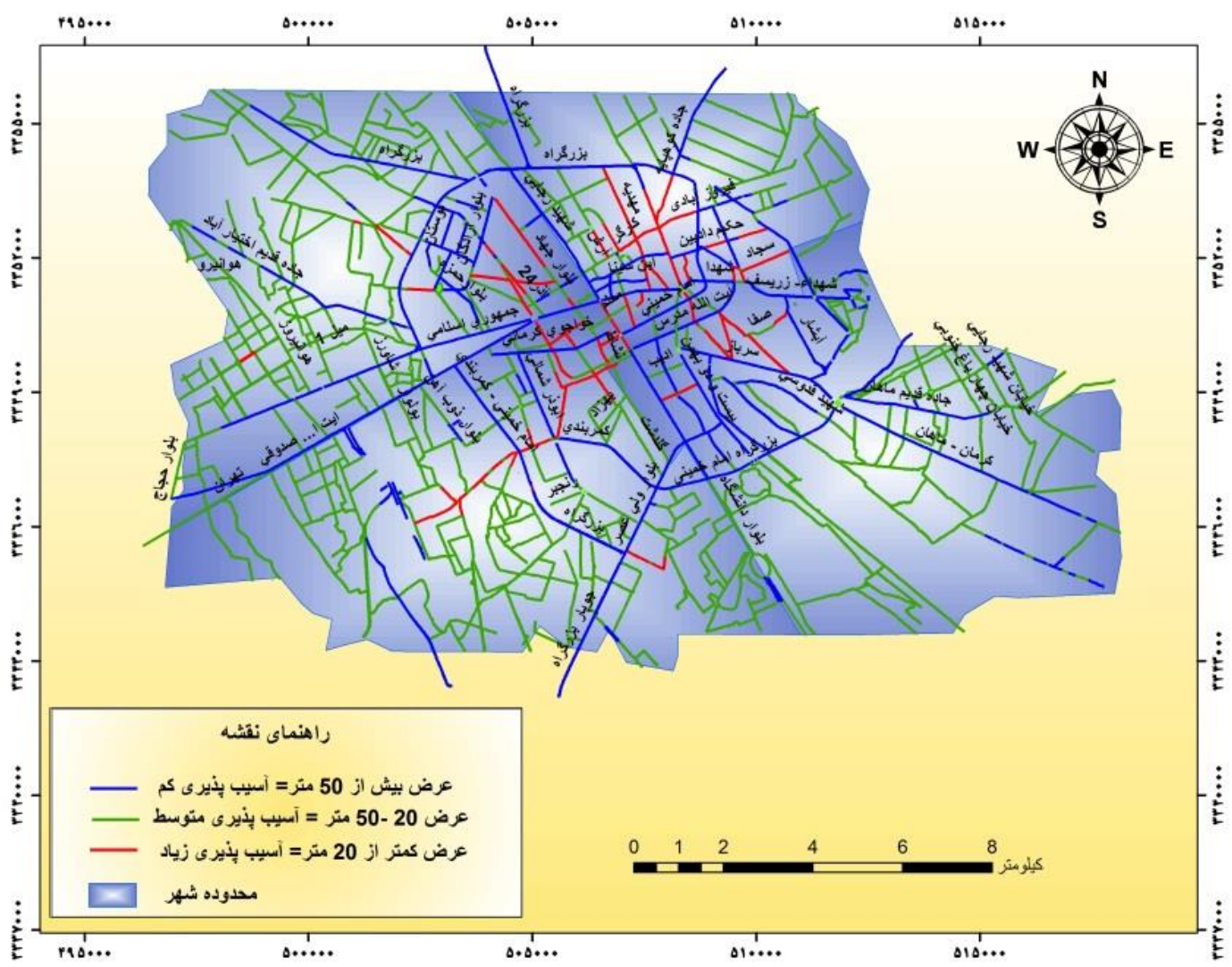

شكل rا : نقشه آسيب يذيرى شبكه حمل و نقل منطقه موردمطالعه بر اساس عرض مسيرها.

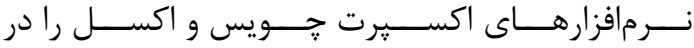

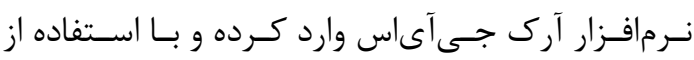
توابع تحليلى تمام نقشه هاى معيارهـاى آسـيبـيـذيرى إنى

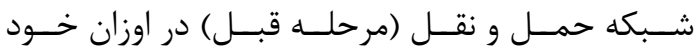

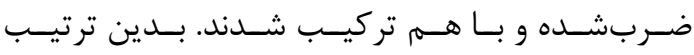

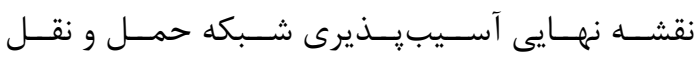
شهر كرمان مطابق شكل (rاן) تهيه كرديد.

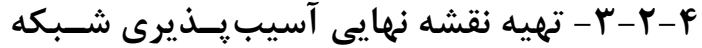
حمل و نقل منطقه مور دمطالعه

با نظر به اينكه آسيبيذيرى تابعى از هند معيـار اسـت

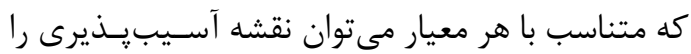

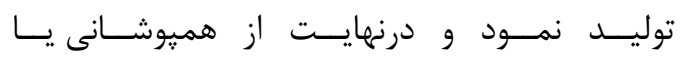

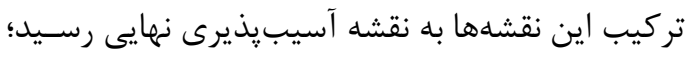

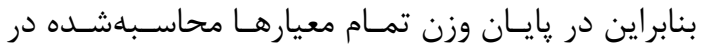


رزيابى آسيبيذيرى لرزهاى شبكه حمل و نقل با تأكيد بر...

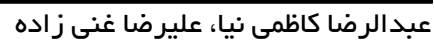

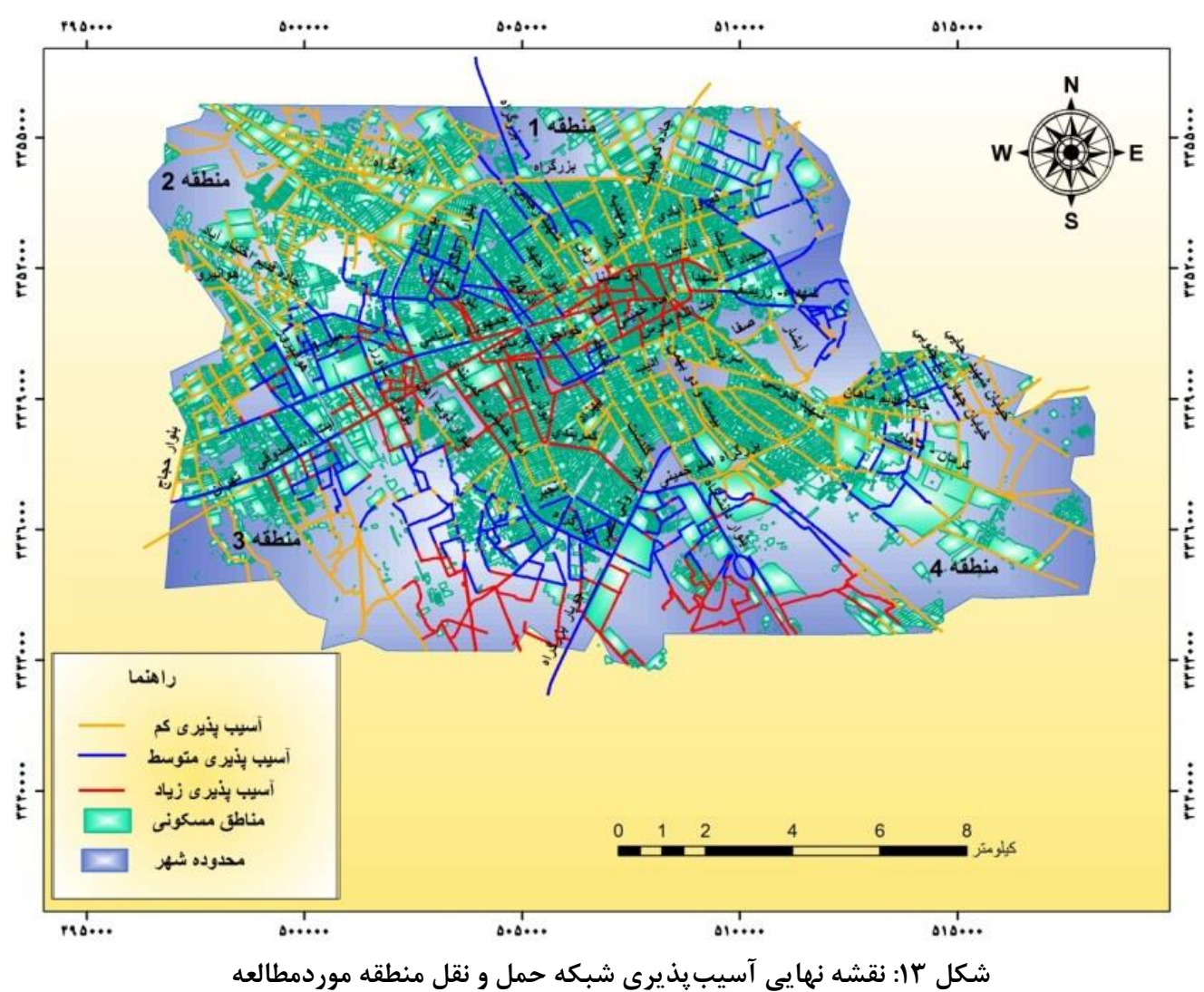

مسيرهاى شبكه حمل و نقل منطقـهـ بــر اسـاس نـوع و طول به سه گروه كوجه، خيابان فرعى و خيابان شريانى

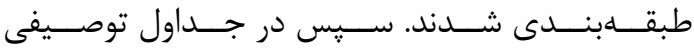

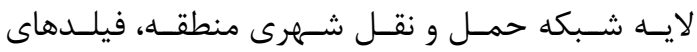

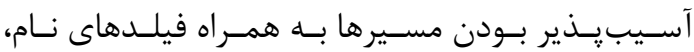

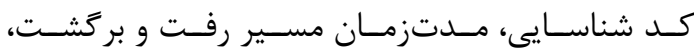
يكىطرفه و دوطرفه بودن، طبقهبنـدى و طـول مســيرها ايجاد و اطلاعات توصيفى مربوطه وارد گرديد. بعـدازاين مراحل، شبكه هندسـى حمـل و نقـل شـهر كرمـان بـا در نظر گرفتن فيلدهاى طول، يك طرفه- دوطرفه بودن

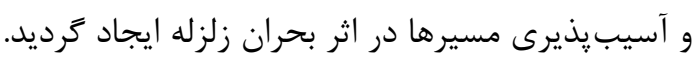

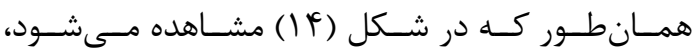
مى توان با به كار بردن تحليل هاى شبكه در هنگًام زلزله يا بعدازآن، بهراحتى بهترين مسير نجات آسيب ديدان بـان

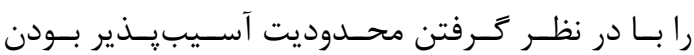
شبكه حمل و نقل، تعيين نمود.
F-r - - طراحى و ساخت شبكه حمل و نقل منطقــه موردمطالعه

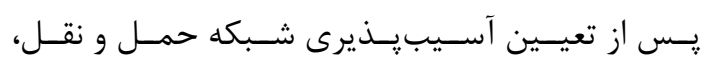
براى خدماترسانى و تخليه سـريعتـر آسـيب ديـدكان هنگام و بعد از بحران، يك يايگاه داده زمين مرجع براى معابر شهر كرمان طراحى گرديد. بـهايسن منظـور ابتـدا

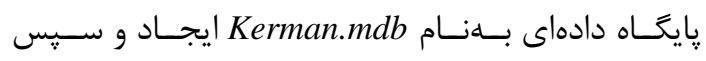

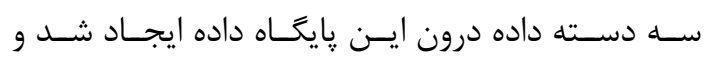

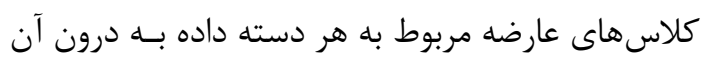
وارد گرديدند. براى يافتن خطاها در دادههـاى ورودى و

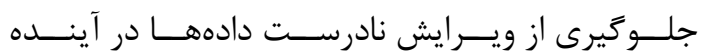

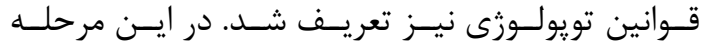

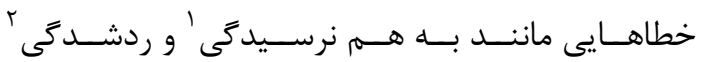

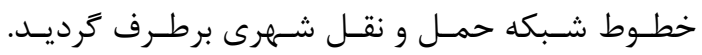

\footnotetext{
${ }^{1}$ Undershoot
}

${ }^{2}$ Overshoot 


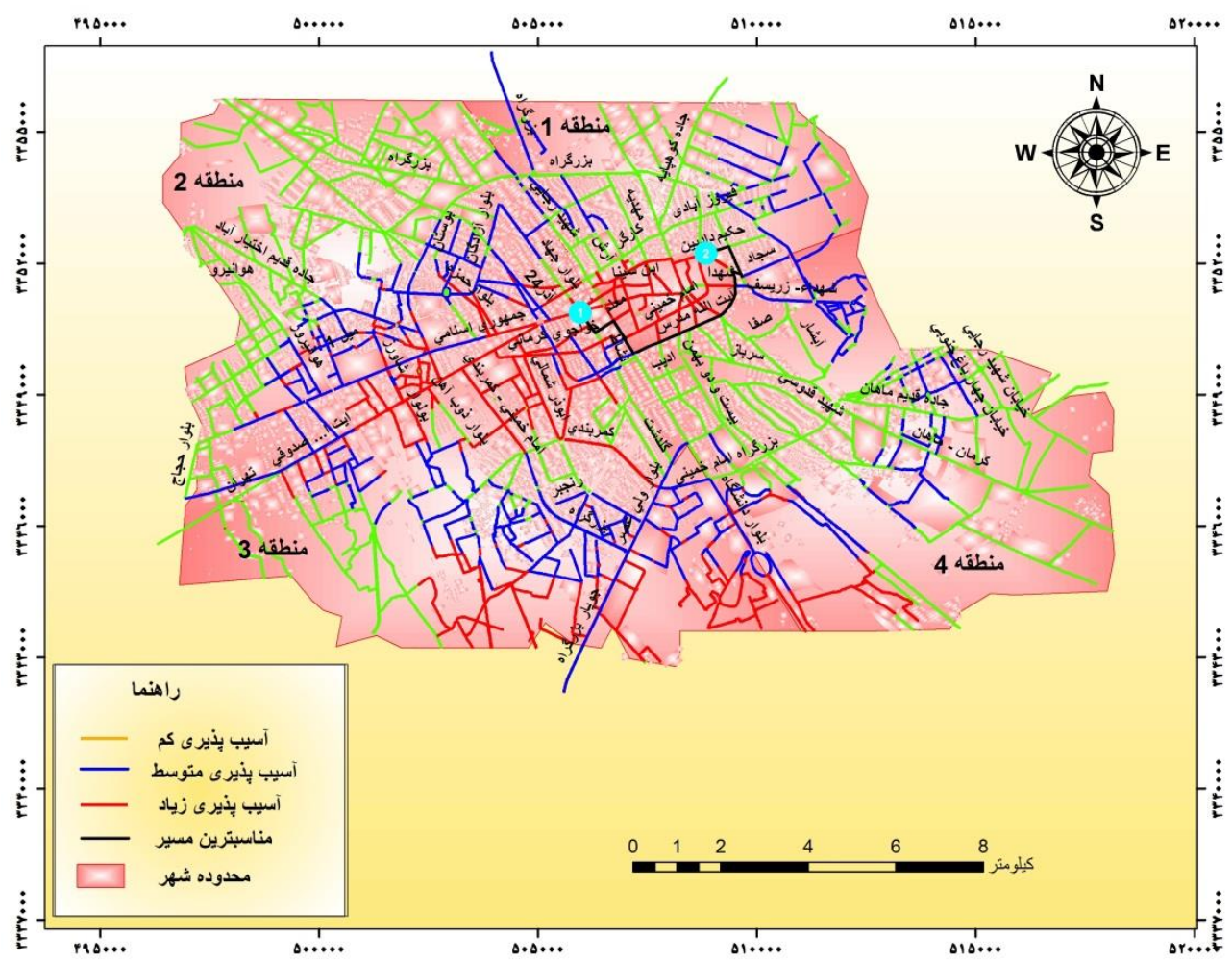

شكل If نقشه تعيين مناسبترين مسير بين مبدأ (1) و مقصد (Y) شبكه حمل و نقل شهر كرمان با در نظر كرفتن محدوديت آسيبريذير بودن در برابر زلزله.

رويكرد بحران زلزله، معلول يـك معيـار آسـيبـيـذيرى خاص نيست بلكه، برآيند مجموعهاى از عوامل و معيارها

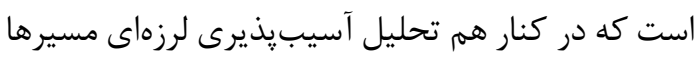

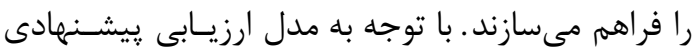

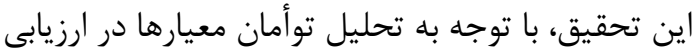

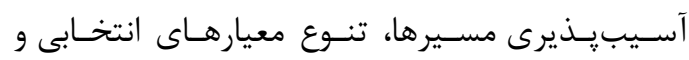
تشابهات كالبدى مسيرهاى شهرى در اكثر نقاط كشور، مسىتوانــد از كـارآيى و مطلوبيـت لازم برخـوردار و و

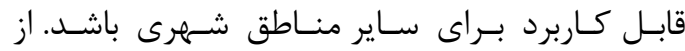

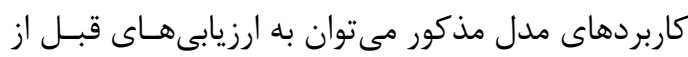

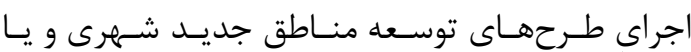
شهركهاى جديد باهدف تعيين ضوابط تراكم جمعيتى

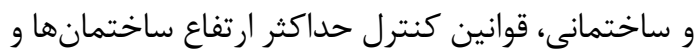

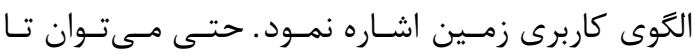

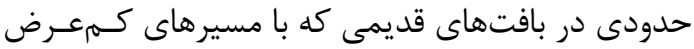

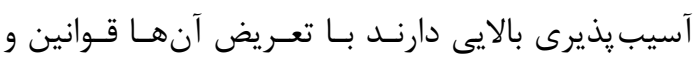

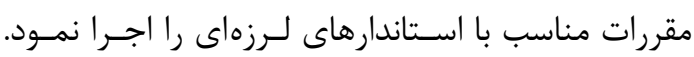

ه- - نتايج و وييشنهادها

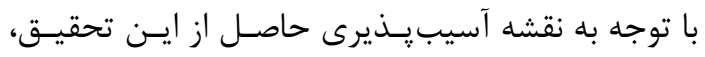

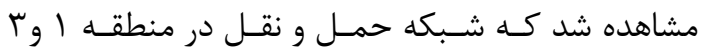
نسبت به ساير مناطق ديخر آسيب يذيرى بـالاترى دارد.

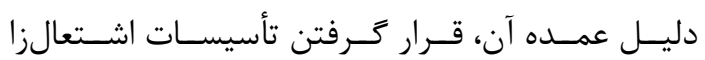

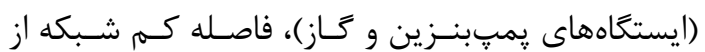

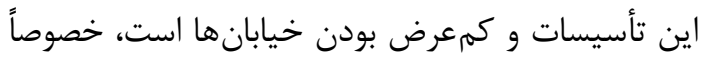
منطقه ا كـه بافت قـديمى شـهر را شـامل مسىشـودي. همجنين مقاومت زمين ازنظر خطر روانكرايى و جنبش إنش زمسين در منـاطق ا و r وزن بيشـترى راد دارد. تعيسين

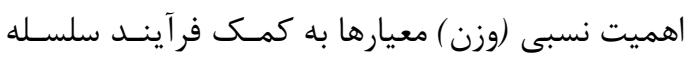
مراتبى تحليل سلسله مراتبى نشان داد كه معيـار خطــر

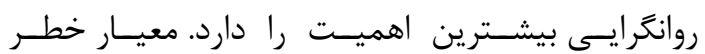

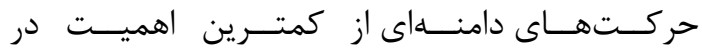

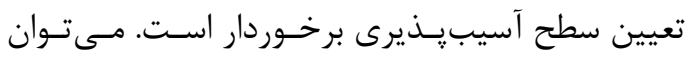

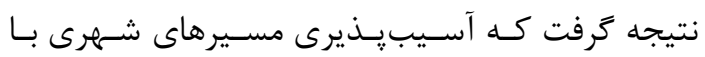




$$
\begin{aligned}
& \text { جمعيتى در مطالعات آتى استفاده شود. در مقايسه ايـن }
\end{aligned}
$$

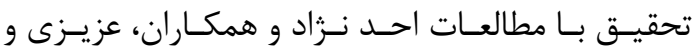

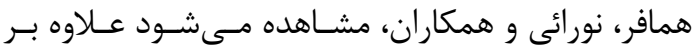

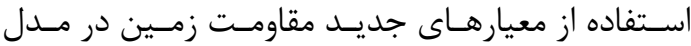

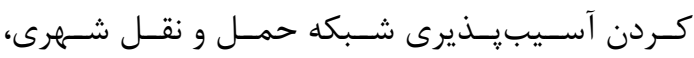

$$
\begin{aligned}
& \text { اجراى تحليلهاى شبكه مانند يافتن بهتـرين مســير بـا }
\end{aligned}
$$

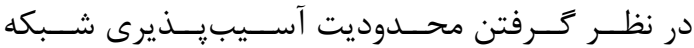

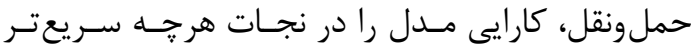

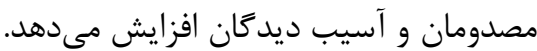

[1] H. Ranjbar, A.Azmodeh Ardalan, H.Dehghani,M. Serajiyan and A. Alidoosti, " Facilitate the reactive phase of earthquake disaster management with automatic extraction of buildings based on tissue analysis of satellite images ", Journal of Disaster Management, Vol. 5, PP.5-19, 2014.

[2] M. Zanganeh," Assessment and risk analysis solutions for civil defense and the road network in Alborz province using methods IHWP and SWOT ", Journal of Geographic information, Vol. 98, PP.113-128, 2016.

[3] NC. Balijepalli and O. Oppong, " Measuring Vulnerability of road network considering the exent of serviceability of critical road links in urban areas", Journal of Transport Geography, Vol. 39, PP.145-155, 2014.

[4] M. Hosseini, "A Method For The Seismic Vulnerability And Functionality Assessment Of Transportation Systems In Large Cities", Proceedings of the 12th European Contention on Earthquake Engineering, Elsevier Science Ltd., London , 2002.

[5] H. Homayoni, N. Rezaei, R.A. Abbaspor " Local communication network performance evaluation and spatial analysis after the earthquake in terms of civil defense ", Journal of Science and Technology of Civil Defense Vol. 3, PP.151-160, 2011.

[6] P. Tung," Road vulnerability for earthquakes

$$
\begin{aligned}
& \text { همجنين در نواحى با آسيب يذيرى زياد و احتمال خطر } \\
& \text { بيشتر هنگام زلزله مىتوان با توسعه و كسترش فضاهاى ناي }
\end{aligned}
$$

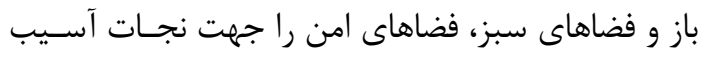

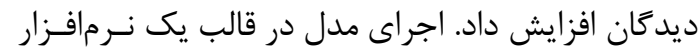

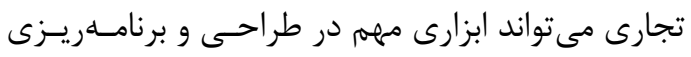

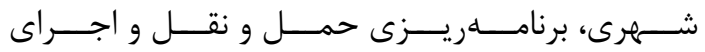

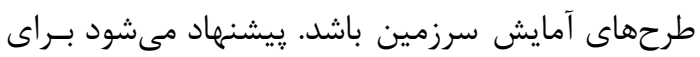

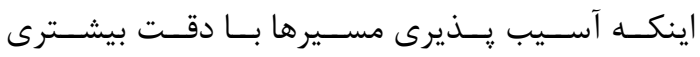

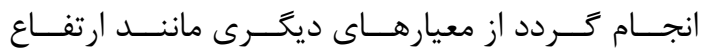

$$
\begin{aligned}
& \text { ساختمانهاى اطراف مسـيرها، طــول مسـيرها و تـراكم } \\
& \text { مراجع }
\end{aligned}
$$

(A case study of Lalitpur, Kathmandu Nepal)", Mark Brussel Press, Brussel,2004.

[7] M.Taylor, and G. Este, "Transport Network Vulnerability: a Method for Diagnosis of Critical Locations in Transport Infrastructure Systems", Transport Systems Centre, University of South Australia, Australia,2006.

[8] F. Bono, E. Gutiérrez,. "A network-based analysis of the impact of structural damage on urban accessibility following a disaster: the case of the seismically damaged Port Au Prince and Carrefour urban road networks", Journal of Transport Geography, Vol.19, No.3, PP.1443-1455, 2011.

[9] Q. Dalin and Y. Luping, "Vulnerability Analysis of Road Networks", Journal of Transportation Systems Engineering and Information Technology Vol. 12, No. 1, PP.23-41, 2012.

[10]T.Nagae, T. Fujihara and Y.Asakura, "Antiseismic reinforcement strategy for an urban road network", Transportation Research Part A, Vol. 46, No.2, PP.813827,2012 .

[11] J. Lambert, A. Parlak, Q.Zhou, J. Miller and M. Fontaine, " Understanding and managing disaster evacuation on a transportation network", Accident Analysis and Prevention, Vol. 50, PP.645-658, 2013.

[12] M.M. Azizi and M. Homafar, "Identify of 
seismic damage of Urban pathway", Journal of ART, Vol. 17, No. 3, PP.5-15, 2012.

[13]M. ahadnejad, SH. Rostaei and M.M. Kamelifar, " Urban street network for seismic vulnerability assessment approach to crisis management Case Study: Region 1 Tabriz ", Journal of Geographic information, Vol. 95, PP.37-50, 2015.

[14]Z. Nezhad Akbari and M. Mojarrad Kahani, " Vulnerability scanning and blocking streets after the earthquake Case Study: Law enforcement centers in Kerman ", Journal of Geography law, Vol. 9, PP.69-92, 2015.

[15] Y. Ebrahimian Ghajari, A.A. Alesheikh, M. Modiri, R. Hasanvi and M. Abbasi " Building the ultimate urban vulnerability modeling using Delphi and AHP in GIS ", Journal of Geographic information, Vol. 91, PP.5-20, 2014.

[16]D.Hidalgo and C. Huizenga, "Implementation of sustainable urban transport in Latin America", Research in Transportation Economics, Vol. 40, No. 1, PP.66-77, 2013.

[17] O.Azari and F. Karimi poor, " Urban routing based model for temporal or spatial data used by the Wide ", Twentieth National Conference on Geomatics,Tehran, 2013.

[18]C. Cheng, Y. Zhou , K. Yue and J. Yang, " Study of SEA Indicators System of Urban Green Electricity Power Based on Fuzzy AHP and DPSIR Model", Journal of town and country planning, Energy Procedia, Vol. 12, No. 3, PP.155-162, 2011.

[19] R.Hasanzadeh, A. Abbasnezhad, A. Alavi and E. Sharifi, " Seismic risk analysis of Kerman with an emphasis on micro-zoning application of GIS in qualifying Tier 2", Journal - of Earth Sciences, Vol. 81, PP.23$30,2010$.

[20]S. Meimandi and A. Kazeminia, Assessment and zoning of Kerman city vulnerability based on the principles of passive defense Using Delphi and GIS-AHP model ", Journal of town and country planning, Vol. 7, No. 1, PP.119-144 2015.
[21] Gutiérrez, E., Taucer, F. De Groeve, T. AlKhudhairy, D. H. Zaldivar, J. M.(2005). "Analysis of Worldwide Earthquake Mortality Using Multivariate Demographic and Seismic Data", American J.Epid, Vol.161,No. 12, PP. 1151-1158.

[22] Thanh, P.(2004). "Road vulnerability for earthquakes (A case study of Lalitpur, Kathmandu -Nepal) ", Mark Brussel Press, Brussel. 


\title{
Evaluation of Seismic vulnerability of transport networks with an emphasis on criteria earth resistance and design of routes and rescue using GIS
}

\author{
Abdolreza Kazeminia*1,Alireza Ghanizadeh $^{2}$ \\ 1- Lecturer in Department of Civil Engineering, College of Civil Engineering,Sirjan University of Technology,Sirjan,Iran. \\ 2- Assisstant professor in Department of Civil Engineering, College of Civil Engineering,Sirjan University of Technology,Sirjan,Iran.
}

\begin{abstract}
Transport networks are the main foundation of continuous development of regions due to its importance to economic, industry, political, and even military. Public transportation network becomes significantly important before and after earthquakes, rescue operations, and displacement and evacuation of victims. Hence, geometric network design and planning of urban transport to reduce potential injuries seem vital. The Kerman city due to its geographical location and being trapped within earthquake faults is vulnerable. In this work, we studied the Kerman urban transport network vulnerability against earthquakes resistance based on criteria Earth and using GIS- AHP by defining the reference database for urban routes, to serve and to drain injuries faster during or after earthquakes. In descriptive tables, the layer of city routes, vulnerability of fields along with route name, identification code, being a one-way or two-way route, classification, and route lengths are documented. When required, by applying network analysis such descriptive tables can be used to find the best route to rescue victims. Results show that the most vulnerabile transport networks in the Kerman city are in regions 1 and 3 which is due to accumulation of vulnerable urban facilities and low-resistant ground in these areas. Hence, these regions should be considred as highest priority in planning.
\end{abstract}

Key words: Urban transport network, Vulnerability, geometric network, Earthquake

Correspondence Address: Department of Civil Engineering, Sirjan University of Technology,Sirjan, Iran Tel: Tel:+98 3442336905

Email: Kazeminia@Sirjantech.ac.ir 